\title{
Revitalizing Cultural Characteristics in Advertising in Nigeria Within a Sketch of Systemic Paradigm*
}

\author{
Taofeek O. Dalamu** \\ Gbenga Ogunlusi***
}

Received: 2020-02-15 - Sent in pairs: 2020-02-28

Peer approved: 2020-03-20 Accepted: 2020-05-22

https://doi.org/10.22395/angr.v19n37a2

\begin{abstract}
This study investigated cultural pieces of advertising to indicate the ways that publicists deploy socio-cultural resources as normative channels of persuading readers to consumption. To achieve that goal, ten advertisements of financial, food, and telecommunications industries, harvested from The Punch newspaper, the Internet and erected advertising frameworks, functioned as data of analysis. After stratifying the advertisements into appropriate organizations, the terminology of 'Below the clause', functioned as the processing instrument. This allowed the application of graphic illustrations to account for the frequency of communicative components. The analysis revealed the employment of nominal groups (the lessons; this Eid) as playing dominant roles in the constructs, verbal groups (taste; celebrate) and prepositional phrases (from all of us at Fidelity Bank ${ }^{\boxplus}$; of commerce), also operated as stimulating structures. Although negligible, minor clause (Happy Workers' Day; Eid Mubarak) are relevant grammatical elements of inducement. Besides anchorage and relaying functions interlocking the texts, one observed ambiguity (your work; Bae) in the Union Bank ${ }^{\circledast}$ and Wema Bank ${ }^{\circledR}$ advertisements. Connotations facilitated the communication of Mama don land and the big bottle of Coca-Cola ${ }^{\circledR}$; the spirit of our nation and green-white-green dresses; your work and Maman Aisha; and the sacrifice of Christ with the crown of thorns. Contexts such as Yorùbá traditions, family affairs, religious nuances, savings, and historical notions are propagated cultural endowments that influenced the advertisements' meaning potential. As a result, the analysts might suggest that advertisers ought to consistently decorate their campaigns with cultural fortunes. Such behavior has the capacity to educate and influence readers to consumption in their various regional domains.
\end{abstract}

Keywords: advertising group; culture; determinate; indeterminate; nominal group; prepositional group; verbal group.

\footnotetext{
This article is a product and part of the authors' on-going research efforts to explain the structures, contents, and communicative models of advertising in Nigeria from a purely systemic functional linguistics' perspective. The project started on 2016 and has been consistently funded by Bashy Motors Lagos, Nigeria.

* Dr. Taofeek Dalamu obtained a Ph.D. in english as a specific language from the University of Lagos. As a faculty member, he currently teaches English at the Department of English and Literary Studies, Anchor University, Lagos, Nigeria. He specializes in Systemic Functional Linguistics, Discourse Analysis and Digital Humanities in relation, mostly, to advertising communications. Dr. Dalamu is a member of International Systemic Functional Linguistics Association (Isfla), exhibits a variety of 29 publications in reputable international journals across the globe. Email: tdalamu@aul.edu.ng; Orcid: http:// orcid.org/0000-0002-5494-4854

".. Dr. Gbenga Ogunlusi obtained a Ph.D. in Business Administration from Obafemi Awolowo University, Ile Ife (formerly known as University of Ife). His interest is in service marketing, product development, and business research methods. He has twelve publications in both international and local journals. At present, Dr. Ogunlusi teaches Marketing and Management courses in the Department of Administration and Management, and is the Acting Director of General Studies units, at Crawford University, Faith City, Igbesa, Nigeria. Email: ogunlusi.gbenga@crawforduniversity.edu.ng; Orcid: orcid.org/0000-0001$8912-8235$
} 


\section{Revitalizar las características culturales de la publicidad en Nigeria en el marco del paradigma sistémico}

\section{Resumen}

Este estudio investigó piezas culturales de publicidad para indicar las formas en que los publicistas utilizan los recursos socioculturales como canales normativos para persuadir a los lectores al consumo. Para lograr ese objetivo, se emplearon a manera de datos de análisis diez anuncios de industrias financieras, alimentarias y de telecomunicaciones, obtenidos del periódico The Punch, internet y marcos publicitarios. Después de estratificar los anuncios en las organizaciones apropiadas, la terminología "por debajo de la cláusula", funcionó como instrumento de procesamiento. Esto permitió la aplicación de ilustraciones gráficas para tener en cuenta la frecuencia de los componentes comunicativos. El análisis reveló el empleo de grupos nominales (las lecciones; este Eid) con un rol dominante en las construcciones, grupos verbales (sabor; celebraciones) y frases de preposición (de todos nosotros en Fidelity Bank ${ }^{\circledR}$; de comercio); que también actuaban como estructuras estimulantes. Aunque insignificantes, las cláusulas menores (feliz día del trabajador; Eid Mubarak) son elementos gramaticales relevantes de inducción. Además de las funciones de anclaje y retransmisión que interconectan los textos, se observó ambigüedad (su trabajo; Bae) en los anuncios de Union Bank ${ }^{\circledast}$ y Wema Bank ${ }^{\circledR}$. Las connotaciones facilitaron la comunicación de Mama don land y la botella grande de Coca-Cola ${ }^{\circledR}$; el espíritu de nuestra nación y los vestidos verde-blanco-verde; su trabajo y Maman Aisha; y el sacrificio de Cristo con la corona de espinas. Contextos como las tradiciones yorùbá, asuntos familiares, matices religiosos, el ahorro y nociones históricas son dotaciones culturales propagadas que influyeron en el potencial del significado de los anuncios. Como resultado, los analistas podrían sugerir que los anunciantes deberían adornar sus campañas de manera consistente con aspectos culturales apreciados por el público. Ese comportamiento tiene la capacidad de educar y manipular a los lectores para que consuman en sus diversos dominios regionales.

Palabras clave: grupo publicitario; cultura; determinado; indeterminado; grupo nominal; grupo preposicional; grupo verbal.

\section{Revitalizando caraterísticas culturais na publicidade da Nigéria no contexto de um paradigma sistêmico}

\section{Resumo}

Este estudo pesquisou peças culturais de publicidade para indicar as formas como publicitários empregam recursos socioculturais como canais normativos para persuadir os leitores a consumir. Para atingir esse objetivo, dez peças de publicidade das indústrias financeira, de alimentos e telecomunicações coletadas do jornal The Punch, da internet e de estruturas constituídas de publicidade serviram como dados para a análise. Após classificar a publicidade dentro das organizações adequadas, a expressão "por baixo da oração" ("below the clause"), serviu como instrumento de processamento. Isso permitiu a aplicação de ilustrações gráficas para evidenciar a frequência de componentes comunicativos. A análise revelou o uso de grupos nominais (the lessons; this Eid) desempenhava um papel dominante nos constructos, grupos verbais (taste; celebrate) e orações preposicionadas (from all of us at Fidelity Bank ®; of commerce), também operavam como estruturas estimuladoras. Mesmo que insignificante, orações menores (Happy Workers' Day; Eid Mubarak) são elementos gramaticais relevantes da persuasão. Além da ancoragem e das funções de retransmissão que interconectam os textos, foi observada ambiguidade (your work; Bae) na publicidade do Union Bank $\AA^{\circledR}$ e Wema Bank®. Conotações facilitaram a comunicação da Mama don land e a garrafa grande de Coca-Cola®; the spirit of our nation e vestidos verde-branco-verdes; your work e Maman Aisha; e o sacrifício de Cristo com a coroa de espinhos. Contextos tais como os das tradições Yorùbá, situações de família, nuances religiosas, poupanças e noções históricas são dotes culturais propagados que influenciaram no potencial do significado da publicidade. Como resultado, os analistas poderiam sugerir que os publicitários devessem ilustrar de forma consistente suas campanhas com fortunas culturais. Este comportamento tem a capacidade de educar e influir aos leitores ao consumo em seus vários domínios regionais.

Palavras-chave: agência de publicidade; cultura; determinar; indeterminar; grupo nominal; Grupo preposicional; grupo verbal. 


\section{Introduction}

Cultural inclinations seem indisputable ways of life for humankind. The reason is that cultural evidence, in multifaceted dimensions, reveals the identities of people in relation to social, professional, religious, and perhaps, academic exercises (Triandis, 1972; Hall, 1976). Thus, human lives and cultural values are two parameters of a kind, demonstrating unbroken ties. Owing to this claim, the culture of people defines who people actually are (Harris, 1976). The paramount-cum-deep-seated position of culture in human settings appears to have motivated advertising professionals to perceive the concept of culture as a norm in the business of persuasion (Mueller, 1987; De Mooij, 2015). Advertisers utilize cultural contexts to create unremitting bonds between the consumer and the product (Pollay, 1983; Hornikx \& O'Keefe, 2009).

The notion of culture in this framework points to all characteristic qualities that are common to a group of people (Allwood, 1990; Pérez Flores \& Muñoz Sánchez, 2018). In other words, culture represents what Samovar, Porter, and McDaniel (2009) construct as a behavioral complex whole, which is revealed as the art, custom, belief, moral, and knowledge of a people. In that regard, culture operates as a conglomerate of events learned by a society, and it is upon that composite value that laws, guiding and governing individuals, take a course. In addition to that view, Hofstede and Hofstede (2005) argue that the cultural treasure is a line of demarcation that distinguishes one group from another, one community from another and one nation from another. The complexity of cultural values makes the term an intricate-entwining device.

Besides, cultural features have distinctions from various levels of human endeavors and societies. One might not be amazed for Hofstede and Hofstede to have coined culture as "a collective programming of the mind" (2005, p. 4), setting a pattern of differentiation and discernment from one human dominion to another. It is worth stressing that cultural treasures are identifiable across families, gender worth, organizations, age relevance, and national bearings (De Mooij, 1998). Against this backdrop, social events of children, youths, old men and women, and professional bodies have become the capitalists' instruments for stimulating readers to consumption (Dalamu, 2017). In that wise, publicists tend to transform cultural proprieties, functioning as human identities, into symbolic elements of eco-financial generation of manufacturers' capital balance sheet (Song, Ahn \& Sung, 2014).

Culture and human beings are jointly operational in facets of life (Hofstede, 1980; Hoffman, Schwartz, Dalicho \& Hutter, 2014). One might comment that the parameters of studying the alliance of culture with mankind cut across business management, anthropology, communication, sociology, philosophy, education, and linguistics (Kizltan \& Ayar, 2020). Consequently, scholars (Hall, 1976; Sun, D'Alessandro, Johnson 
E Winzar, 2014; Cook, 2001; Carter \& Nash, 2013; Myers, 1994; Ahangar, Taki \& Rahimi, 2017) have discussed the relationships of culture with advertising. Nevertheless, researchers observe such inseparable association within mono-cultural heights (Zhang E Shavitt, 2003; Khanh \& Hau, 2007), national cultural widths (Polyorat \& Alden, 2005; Xue, 2015), and inter-cultural capacities (Zhang, 2014; Theocharous, 2015; Kim, Jeong E Hwang, 2016).

Particularly, there are cultural investigations about humor in advertising across cultures (Alden, Hoyer $\&$ Lee, 1993), visual and verbal profiles (Niaz, 2001) manifestation of nudity (Nelson \& Paek, 2008), cultural entertainment (Fam, 2008), and religious values augmenting cultural qualities. Gelbrich, Gathke and Westjohn (2012) investigate absurdity as a strategy of advertisers' sensitization, while Hsu and Barker (2013) connect their research to the influences of cultural fortunes on American and Chinese target audiences. Bakir, Palan and Kolbe (2013), Moon and Chan (2005), and Chang (2006) focus on the issue of children; Prieler and Centeno (2013) analyze gender stereotypes in advertising. The concerns of Gevorgyan and Manucharova (2015), and Lee, Khang and Kim (2016) explore how advertisers display cultural etiquettes as an ethnic identity in political campaign advertisements (henceforth: ad/ads).

Significantly, cultural principles function in the form of images and texts in advertising communications (Hall, 1976; Sells \& González, 2002; Hofstede \& Hofstede, 2005). That refers to the employment of image and text as the social discourse of enticing the audience (Andrioli \& Ostermann, 2019). Thus, the social contents of image and text are the crux of this study, however it limits are found within the agenda of Nigerian contexts. By implication, this research explains cultural elements and settings such as traditional assets, indigenous occupational models, religious ties, and national treasures as devices for inspiring readers to consumption. This work, as a contribution to earlier studies, prides itself in utilizing Halliday and Matthiessen's (2014) 'Below the clause' in collaboration with Cook's (2001) determinate and indeterminate terminologies to analyze the pictorial and textual contents of ads. The basis is to deduce the meaning potential of advertising nuances as being accommodated in Nigerian cultural treasures.

\section{Literature Review}

The interdisciplinary appearance of this study stimulates the authors to address the literature review from two perspectives of business and linguistics. Therefore, the literature review covers dimensions of culture in relation to advertising propagation, as well as the concepts of 'Below the clause', and determinate and indeterminate, which are tools for analyzing ads and discussing their communicative components. 


\section{Dimension of Culture (in/and Advertising)}

Historical accounts report that German writers, about 200 years ago, practice culture in relation to derivational sociological meanings. However, Burke (2008) attests that culture is Latinized from the lexicon 'cultura.' As been utilized by Roman writers, 'cultura' means 'cultivation.' The notion of 'cultivation' represents a deliberate development of certain features around an individual or a group of like-minded people. The calculated intention could be for the purpose of identity differentiation. Such recognition might have informed Hofstede (1980) to articulate that culture is "[...] the interactive aggregate of common characteristics that influences a group's response to its environment" (p. 19).

Hofstede's point of view suggests culture as a device, enabling a pattern of conduct, fundamental to a group of people in society. This could lead to individual receptivity or collective sensibility. Thus, the matter of social behavior of an individual and social control anchors on culture. In a similar measurement, the outcome of human interactions and collective activities, in Hall's (1976) epitome, is a medium of:

how people express themselves, the way they think, how they move, how problems are solved, how their cities are planned and laid out, how transportation systems function and are organized, as well as how economic and government systems are put together and function. (p. 14)

Culture, in Hall's (1976) sense, is a complete way of life of humankind in all ramifications. Therefore, one could deduce that Hofstede and Hall are prominent theoretical apostles of cultural models. Hofstede (1980) considers four dimensions of individualism/collectivism: 1) power distance, 2) uncertainty avoidance, 3) masculinity/feminity, and 4) long-term orientation as the cultural typological substantiations. Nonetheless, Hall's (1976) cross-cultural communication framework hovers around images that exhibit contextual variations. On the one hand, Hall (1976) asserts that this standpoint is high- and low-contexts in the vector of information dissemination as a channel to produce appropriate meaning potential. On the other hand, Hall propagates the cultural model in terms of the kind of relationship operating between two individuals, the setting of communication, and the differences that function between the custodian of a culture and an intruder.

The impression of individualism, following Maffesoli (2000), points to every person in different groups, organizations, and societies, portraying certain striking but attractive manners. Such images are individuals' lifestyles and values are seriously attached to behaviors (Harris, 1976; Hofstede, 1997). The value of images wholesomely defines the critical paths of the consumer culture as an aesthetic experience. In a smart way, advertising experts are not short of this knowledge. Publicists rather crave for the sig- 
nificance of cultural dimensions, taking advantage of inseparable human cultural styles to sell, in Goddard's (2002) approach, the culture of the people to convince readers.

Nigeria, part of global society, has its culture in every domain of the world. However, its' culture appears to be a complex one. This is owing to the fact that ethnic biases and religious imbalances intervene in the deeds of Nigerian people. In time of necessity, advertisers make references to these discrepancies, other advertising campaigns focus principally on cultural facilities instrumental to unity in the State. On that ground, general or specific styles of Nigerians shape advertising realms. As stated earlier, it is based on cultural etiquettes that the authors have deployed 'Below the clause', and determinate and indeterminate theoretical models to analyze ads, as expatiated below.

\section{Theoretical Paradigm}

Two instruments of analysis govern the conduct of this research. Halliday's 'Below the clause' and Cook's determinate and indeterminate notions. There is a need for these ideas because Daramola (2008) argues that the scope of a study determines the theoretical impressions to be employed.

\section{Below the Clause (BTC)}

It is no gainsaying to state that no one can undermine the efficacy, substance, and magnitude of the clause in Systemic Functional Linguistics (SFL). The clause, in Ravelli's (2000) point of view, plays imperative roles in textual analyses, making concept possessing a domineering prowess in SFL. Notwithstanding, the clause can be fragmented to linguistic structures below it, and the clause can also be extended to facilitate expansion. The former is known as 'Below the clause', the latter is referred to as 'Above the clause' (Eggins, 2004). Moreover, 'Below the clause' is the embodiment of the groups, while 'Above the clause' represents complexity introduced at the clause periphery. In respect to the above submission, this study considers 'Below the clause' as a conceptual schema because the groups have the capabilities to exemplify the nature of cultural contents in advertising textual matters.

The terminology of 'Below the clause' is purely systemic, referring to the rank scale of the clause (Thompson, 2014) of groups and phrases which contribute to the entire meaning of the interaction. Halliday and Matthiessen (2004) depict 'Below the clause' as the grammar of the group, activating in different patterns, and contributing to the semiotic relevance of the clause. 'Below the clause', as Halliday and Matthiessen (2004) emphasize, has "I...] partial contribution to a single structural line" (p. 309) of a complete statement. Sometimes, when a group functions alone as a constructive statement, such constituent might make germane meanings. Advertising textual 
fabrications are good instances of this claim. In a simple term, a group is a distinct construction of words put together to engender a single meaning. That distinction is, perhaps, the motive for Halliday and Matthiessen (2014) to tack the group as an expansion of certain lexicons, as illustrated in figure 1, below.

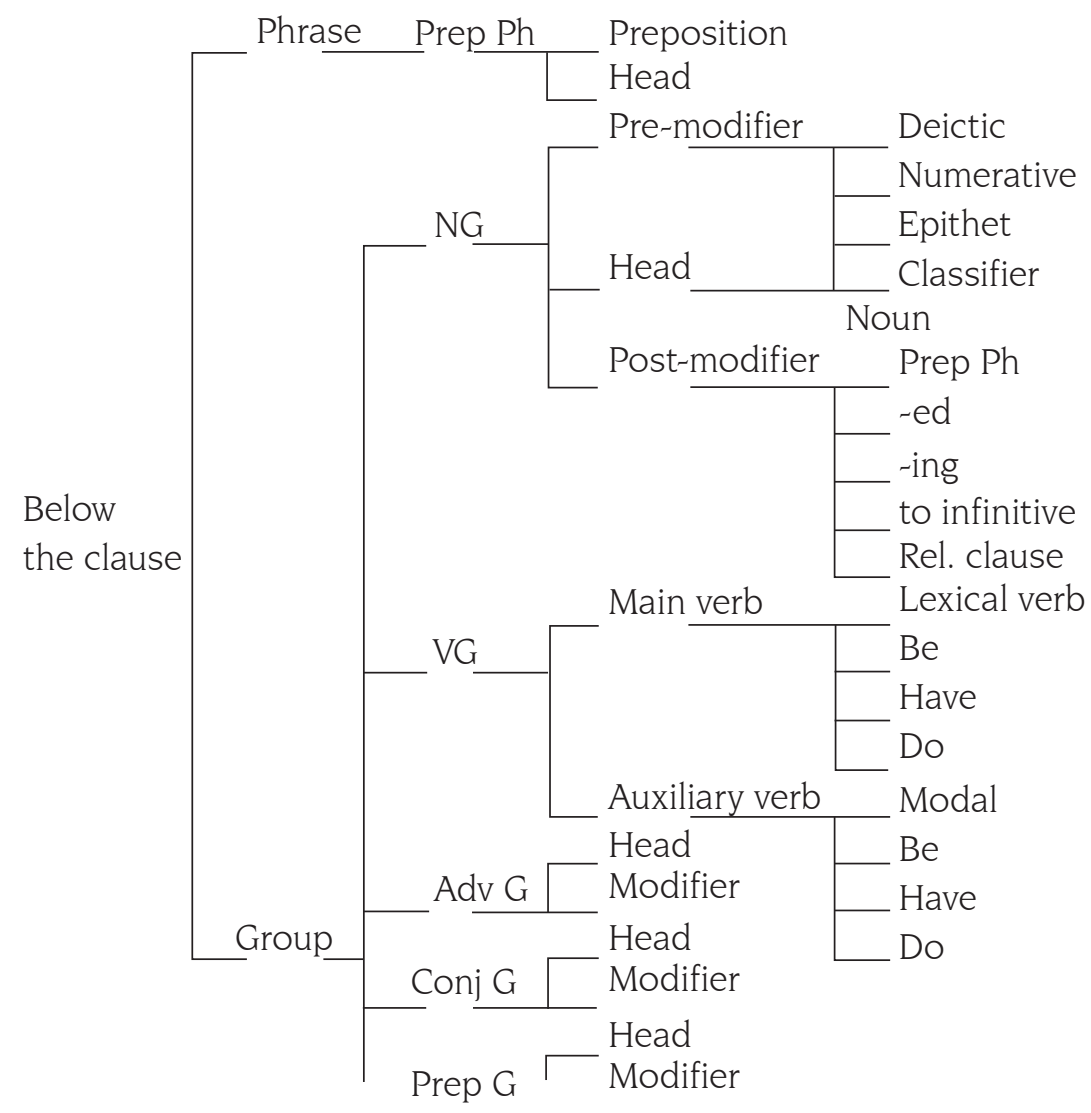

Figure 1. A system of 'Bel ow the clause'

Source: own elaboration.

The system in figure 1 reveals 'Below the clause' as accommodating a phrase and five groups. Prepositional phrase (Prep Ph), in the argument of Bloor and Bloor (2004), serves as a circumstantial adjunct and -once in a while- as an interpersonal adjunct of the clause. Martin and Rose (2013) describe the prepositional structures as Preposition + NG. The embodiment of the groups, in Thompson's (2004) account, shows that nominal group (NG) accommodates pre-modifier + head + post-modifier as functional configurations (Amaral \& Oliveira, 2019). Halliday and Matthiessen's (2014) distinctions of the verbal group (VG) are of the main verb + auxiliaries. Nonetheless, the elements of 'be, have, and do' have the dual strengths to operate, either as the 
main verb or auxiliary in a given clause. Following Bloor and Bloor's (2013) classificatory distribution, adverbial group (Adv G), conjunction group (Conj G), and prepositional group (Prep G) have the head + modifier as their systemic components. Details of groups are also in Poynton (1996) and Fontaine (2013).

\section{Determinate and Indeterminate Notions}

Advertising, an enigmatic enterprise of provoking people to consumption, seems a go-getter and prescriptive business. These qualities inspire the craft to have a close affinity with scientific (plain text) and poetic (hazy text) communicative styles (Dalamu, 2019). The two sides of a coin fall within the conceptual profile of what Cook (2001) labels as the determinate and indeterminate construals.

The impression of determinate points to the interpretation of ambiguous constructions. For Cook (2001), the textual characteristic is common in scientific prose, news reporting, and institutional reports. Determination is denotative. This relativity elucidates an instrument of wheedling that has a fixed meaning, that is commonly shared and easily understood by engaged interactants of a piece of discourse. To a large extent, such communication device exhibits a plain meaningful value. Forceville (1996) connects this type of meaningful persuasive candor or coaxed lucidity to Barthes' (1968) linguistic manifestation of denotation. Denotation implies communicator's style of distributing information in a forthright and transparent way to recipients. The honest textual sequence, in this regard, is accurately self-expressive (Dalamu, 2018a). In other words, denotation presents a text in clear terms, making the construct comprehensible, intelligible, and demonstrating lucidity. On the same semantic geometry, Dyer (2005) characterizes denotation as the first level of meaning deduction in its natural and literal state. Readers use this concept to process language and the understanding of what the text refers to in actual communication domains.

It appears paradoxical to maintain that advertising practitioners construct messages without a particular mission. It is rather more appropriate to support the argument that advertising frames have a crystal clear goal of captivating consumers to buy goods and services (Brierley, 1995). This intention sometimes demands being somewhat crafty and cunning. This is because the goal of enthralling readers to purchase products could be a great task. Therefore, publicists go extra-miles to deploy devices such as puns, euphemisms, and metaphors as aptitudes of cajoling the target audience to consumption. It is the use of these charismatic elements that Cook (2001) considers as the indeterminate notion. The indeterminate construction, otherwise known as connotation, spices up the denotative meaning of an entity. This displays the second system of object's interpretation. As determinate is objective in meaning realization, indeterminate is subjective in decoding meaning. 
The previous is owing to the fact that indeterminate might have culturally-contextual undertones in its representation. Nevertheless, indeterminate resources depend on determinate storage sources to produce meanings. The authors may add that the indeterminate is ambiguous in interpretation simply because of its operational indirectness. Such implicitness might compel readers to have adequate knowledge of codes in order to properly decipher the embedded communicative nuances (Vestergaard $\&$ Schroeder, 1985). To this end, the indeterminate terminology is observable in letters, lexemes, clauses, and pictorial images propagated in advertising plates. Thus, determinate and indeterminate, denotation and connotation are applied in the study interchangeably, without any discrimination.

\section{Research Questions}

The theoretical engagement and cultural supremacy of the study have informed the generation of the following questions:

- How has 'Below the clause' assisted this investigation in revealing the grammatical components of the clauses of the ads to the audience?

- Of what frequencies are the elements of the groups and phrases of the clauses in the advertising frameworks?

- In what ways have the concepts of determinate and indeterminate exhibited the relationships of the texts and images to readers?

- What are the cultural treasures represented in the ads, which advertising practitioners have employed to persuasively motivate recipients to consumption?

Given that, the analysis displays NG as a domineering linguistic structure among the other communicative devices. Moreover, as the spirit of our nation connotes the green-white-green color of the Nigerian flag, so have Yorùbá tradition and religious solemnities function as the profound cultures of galvanizing readers to consumption.

\section{Methodology}

\section{Participants}

Cultural wealth is a probable natural facility of human beings. Advertisers are smart enough to incorporate such a valuable substance into advertising frameworks, displayed in critical places. As a result of that, the collection of ads was retrieved from newspaper, signpost, and Internet. The authors considered The Punch newspaper (for its wide readership), Lagos areas (for being Nigeria's commercial nerve center), and the Internet as domains for gathering ads. These choices propelled researchers to harvest a handful of ads to be stratified, for about ten months between February and November 2018, for appropriate analysis. 


\section{Measures and Design}

A Samsung ${ }^{\circledR}$ camera, an hp ${ }^{\circledR}$ laptop, and an Internet modem assisted the authors to gather thirty ads as the census of different varieties for the sampling process to be applied. The thirty ads from the domains of telecommunications, fast moving consumer goods and banking industry helped to access diverse information in the advertising frames. The sampling process permitted researchers to select a relatively small number of ads from a large group, using as parameters: population, sample, strata and subject (Resinger, 2010). It is worth mentioning that the sampling process is categorized into probability and non-probability procedures. Keyton (2006) compartmentalizes the probability procedure into random, systematic, stratified and cluster methods. The analysts chose the stratified sampling in order to make informed decisions on the basis of limited ads. Moreover, this procedure assisted in reducing cost, and enhanced speed and accuracy (Nwabueze, 2009).

Through the sampling stratified method, the thirty ads were grouped into ten strata, where researchers selected one ad each from each sample strata. However, ten ads were qualified as sample for analysis. The selection of ten ads was to briefly demonstrate to readers the inevitable affinity of ads and Nigerian cultural norms. Perhaps, that could influence great corpus studies in volumes in the future. Owing to the fact that the research focuses on cultural affinities, the kind of cultural treasures in relation to the deployed texts and utilized images was a strong factor that motivated the choice of ads considered for this examination.

\section{Procedure}

The ten ads considered for the analysis were 9 mobile ${ }^{\circledR}$, Fidelity Bank ${ }^{\circledR}$, Heineken ${ }^{\circledR}$, Stanbic IBTC ${ }^{\circledast}$, Zenith Bank ${ }^{\circledast}$, Union Bank ${ }^{\circledast}$, Seaman's Schnapps ${ }^{\circledast}$, UBA $^{\circledR}$ and Wema Bank $^{\circledast}$. As illustrated in table 1 , the analysts organized the communicative elements of the ten ads unto product labels, their textual components, and the nature of their clauses, as well as their numbers. Halliday and Matthiessen's (2004) terminology of 'Below the clause' -as mentioned earlier- predicated on the clauses as a tool for analyzing their kinds and functions. This application permitted the table and graph, following Leech and Short (1981), and Patton (2015), as demonstrated in table 2 and figure 3, to compute the frequency of the groups and phrases as advertisers have employed these structures (Riffo, Osuna \& Lagos, 2019; Sezgin \& Ozturk, 2019). Nonetheless, the discussions adopted Cook's (2001) insights of determinate and indeterminate expressions to throw some light on the association operational between the texts and images.

\section{Data Presentation}

Table 1 below, shows the texts of the chosen ads in their clause forms. The researchers latter analyzed the clause structures in figure 2 . 
Table 1. Texts of the chosen ads

\begin{tabular}{|c|c|c|}
\hline Product & Text & Clause \\
\hline \multirow[t]{2}{*}{ 9Mobile } & TX la & Everyone needs a break \\
\hline & TX $1 b$ & Happy Workers' Day \\
\hline \multirow[t]{4}{*}{ Coca-Cola } & TX 2a & New 1 Litre \\
\hline & TX $2 b$ & Taste the feeling \\
\hline & TX 2c & Mama don land \\
\hline & TX 2d & Also available \\
\hline \multirow[t]{4}{*}{ Fidelity Bank } & TX 3a & The dignity of labour \\
\hline & TX 3b & At Fidelity, we respect honest labour \\
\hline & $\mathrm{TX} 3 \mathrm{c}$ & and celebrate the unsung heroes of our economy \\
\hline & TX 3d & Happy Workers' Day from all of us at Fidelity Bank Plc. \\
\hline \multirow[t]{2}{*}{ Heineken } & TX 4a & Happy Valentine's Day \\
\hline & TX 4b & Open your world \\
\hline \multirow[t]{7}{*}{ Stanbic IBTC } & TX $5 a$ & Eid of Happiness \\
\hline & TX 5b & Eid Mubarak \\
\hline & TX $5 c$ & The fast is over \\
\hline & TX 5d & but the lessons stay with us \\
\hline & TX $5 \mathrm{e}$ & As you celebrate this Eid \\
\hline & TX $5 f$ & Commit to living a healthier, happier and more rewarding life \\
\hline & TX 5g & Stanbic IBTC moving forward \\
\hline \multirow[t]{4}{*}{ Zenith Bank } & TX 6a & As we celebrate the free spirit of our nation \\
\hline & TX 6b & May you experience joy, peace and prosperity always \\
\hline & TX 6c & Happy Independence Nigeria from all of us at Zenith Bank \\
\hline & TX 6d & God bless Nigeria \\
\hline \multirow[t]{4}{*}{ Union Bank } & TX 7a & Your work will make Nigeria work \\
\hline & TX 7b & Mama Aisha Minister of Commerce \\
\hline & TX 7c & Happy workers' Day \\
\hline & TX 7d & Your simpler, smarter bank \\
\hline \multirow[t]{4}{*}{ Seaman's Schnapps } & TX 8a & Seaman's Schnapps \\
\hline & TX 8b & Original prayer drink \\
\hline & TX $8 \mathrm{c}$ & Blessed journey \\
\hline & TX 8d & Drink responsibly \\
\hline \multirow[t]{2}{*}{ UBA } & TX 9a & May the sacrifice of Christ usher you into new beginning \\
\hline & TX 9b & Happy Easter \\
\hline \multirow[t]{4}{*}{ Wema Bank } & TX 10a & Every kobo matters to us \\
\hline & TX 10b & just as it is to \#5kbae \\
\hline & TX 10c & At Wema Bank, we keep your change \\
\hline & TX 10d & Dial $* 945 \#$ to start \\
\hline
\end{tabular}




\section{Data Analysis}

Figure 2 below demonstrates the applications of 'Below the clause' to the advertising constructs of the chosen ads.

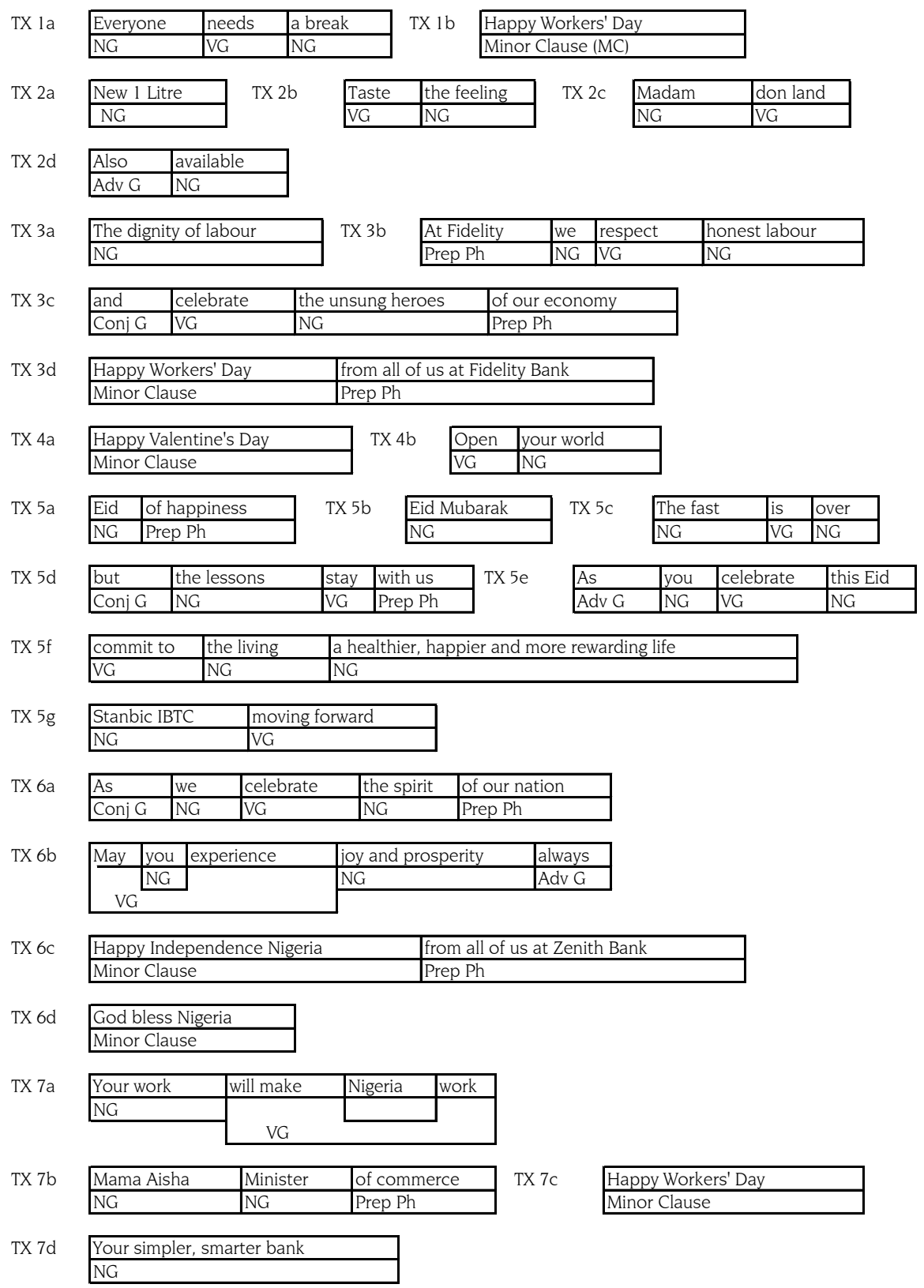

Figure 2. Systemic analysis of the ads

Source: own elaboration 
The study exhibits further analysis of figure 2 at the Results segment.

\section{Results}

This section describes the application of 'Below the clause' to the texts of the chosen ads. Thus, table 2 and figure 3 illustrate the frequencies (Assunção $\&$ Araújo, 2019) of Prep Ph, NG, VG, Adv G, Conj G, and Prep G, as functional linguistic elements in advertising communications.

Table 2. Frequency of 'Below the clause' texts of the ads

\begin{tabular}{|c|c|c|c|c|c|c|c|c|c|c|c|c|c|c|c|c|c|c|c|}
\hline \multirow{2}{*}{ BTC } & \multicolumn{3}{|c|}{ 9mobile } & \multicolumn{3}{|c|}{ Coca-Cola } & \multicolumn{4}{|c|}{ Fidelty Bank } & \multicolumn{2}{|c|}{ Heineken } & \multicolumn{7}{|c|}{ Stanbic IBTC } \\
\hline & TXla & TXIb & TX2a & $\mathrm{TX} 2 \mathrm{~b}$ & TX2C & TX2d & TX3a & TX3b T & TX3C & TX30 & d TX4 & ta TX4 & $4 b$ TX5 & 5a TX5b & $r \times 5 c$ & $=7 \times 5 d$ & TX5e & TX5f & TX5g \\
\hline Prep Ph & 0 & 0 & 0 & 0 & 0 & 0 & 0 & 1 & 1 & 1 & 0 & 0 & 1 & 0 & 0 & 1 & 0 & 0 & 0 \\
\hline $\mathrm{NG}$ & 2 & 0 & 1 & 1 & 1 & 1 & 1 & 2 & 1 & 0 & 0 & 1 & 1 & 1 & 2 & 1 & 2 & 2 & 1 \\
\hline$V G$ & 1 & 0 & 0 & 1 & 1 & 0 & 0 & 1 & 1 & 0 & 0 & 1 & 0 & 0 & 1 & 1 & 1 & 1 & 1 \\
\hline$A d v G$ & 0 & 0 & 0 & 0 & 0 & 1 & 0 & 0 & 0 & 0 & 0 & 0 & 0 & 0 & 0 & 0 & 1 & 0 & 0 \\
\hline Conj $\mathrm{G}$ & 0 & 0 & 0 & 0 & 0 & 0 & 0 & 0 & 1 & 0 & 0 & 0 & 0 & 0 & 0 & 1 & 0 & 0 & 0 \\
\hline Prep G & 0 & 0 & 0 & 0 & 0 & 0 & 0 & 0 & 0 & 0 & 0 & 0 & 0 & 0 & 0 & 0 & 0 & 0 & 0 \\
\hline MC & 0 & 1 & 0 & 0 & 0 & 0 & 0 & 0 & 0 & 1 & 1 & 0 & 0 & 0 & 0 & 1 & 0 & 0 & 0 \\
\hline \multirow{2}{*}{ BTC } & \multicolumn{3}{|c|}{ Zenith Bank } & & Unio & on Ban & \multicolumn{6}{|c|}{ Seaman's Schnapps } & UB & BA & \multicolumn{4}{|c|}{ Wema Bank } & \multirow{2}{*}{ Total } \\
\hline & TX6a & TX6b & TX60 & c TX7a & $\mathrm{TX} 7 \mathrm{k}$ & b TX7c & TX7d & 7d TX8a & a TX8 & $8 \mathrm{~b} \mathrm{TX}$ & X8c T & TX8d & TX9a & TX9b T & PXIOa T & TX10b T & TX10c T & XIOd & \\
\hline Prep Ph & 1 & 0 & 1 & 0 & 1 & 0 & 0 & 0 & 0 & & 0 & 1 & 2 & 0 & 0 & 1 & 1 & 0 & 13 \\
\hline $\mathrm{NG}$ & 2 & 2 & 0 & 2 & 2 & 0 & 1 & 1 & 1 & & 1 & 0 & 1 & 0 & 2 & 1 & 2 & 1 & 40 \\
\hline VG & 1 & 1 & 0 & 0 & 0 & 0 & 0 & 0 & 0 & & 0 & 0 & 0 & 0 & 1 & 1 & 1 & 1 & 17 \\
\hline Adv G & 0 & 1 & 0 & 0 & 0 & 0 & 0 & 0 & 0 & & 0 & 1 & 0 & 0 & 0 & 1 & 0 & 0 & 6 \\
\hline Conj $\mathrm{G}$ & 1 & 0 & 0 & 0 & 0 & 0 & 0 & 0 & 0 & & 0 & 0 & 0 & 0 & 0 & 0 & 0 & 0 & 3 \\
\hline Prep G & 0 & 0 & 0 & 0 & 0 & 0 & 0 & 0 & 0 & & 0 & 0 & 0 & 0 & 0 & 0 & 0 & 0 & 0 \\
\hline $\mathrm{MC}$ & 0 & 0 & 1 & 0 & 0 & 1 & 0 & 0 & 0 & & 0 & 0 & 0 & 1 & 0 & 0 & 0 & 0 & 7 \\
\hline
\end{tabular}

Source: own elaboration

Figure 3, below, recapitulates the linguistic frequencies of 'Below the clause', as displayed in table 1. 


\begin{tabular}{|l|c|}
\hline BTC & Frequency \\
\hline Prep Ph & 13 \\
\hline NG & 40 \\
\hline VG & 17 \\
\hline Adv G & 6 \\
\hline Conj G & 3 \\
\hline Prep G & 0 \\
\hline MC & 7 \\
\hline
\end{tabular}

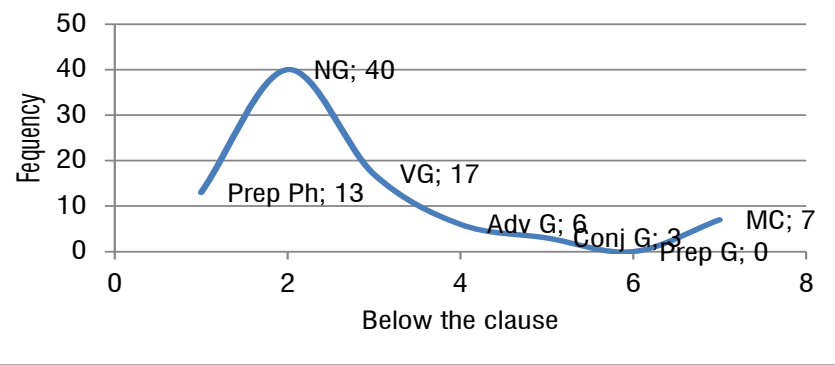

Figure 3. Graphical import of 'Below the clause' texts of the ads

Source: own elaboration.

Out of the seven systemic devices in the concept of 'Below the clause', as demonstrated in figure 3, the advertising professionals consider only six of the linguistic features in order to sway the audience. Consequently, Prep G does not manifest in the communications of the chosen ads. NG of 40 points operates as the most functional element among the other structural items. Figure 3 also reveals VG, with a frequency of 17 , as being the next outfitted device to NG; whereas Prep Ph, recording 13 points, is the third unit of enlivening the public to action. So, NG, VG, and Prep Ph are the major communicative instruments deployed to catch readers' attention to consumption.

The other minor aspects of communicative apparatuses are Adv G of six points and Conj $G$ of three points respectively. These constituents are slightly employed as circumstantial mechanisms, which function as enhancers and binders of the actual intended messages. Another significant communicative facility in figure 3 is the minor clause, which recurs seven different times. This account seems surprising in advertising, except that the minor clauses in the ads are obvious because of the celebration seasons inclined with their propagation. Of note, the ads were campaigned during the Workers' Day, Valentine's Day, Eid celebration, Independence Day, and Easter period. All in all, figure 3 exhibits NG as playing the domineering roles of stimulating recipients to consume goods and services. Thus, one might remark that naming of communicative resources, for a purpose of acuteness, is of utmost priority to advertisers to inspire readers. The content of the clause, as figure 3 shows, is not so much a concern to publicists.

\section{Discussion}

The researchers iterate that this study exemplifies culture from two relational perspectives: of the text and the image. This testimony implies that the two domains are areas at which discussions will focus to clarify communication issues. Doing just that has positioned this investigation, as mentioned earlier, as being interdisciplinary: of business communications and linguistic manifestations. In that respect, the resear- 
chers describe the advertising frameworks in relation to the terminologies of 'Below the clause' (Halliday \& Matthiessen, 2014) and 'determinate and indeterminate' (Cook, 2001). With the structural analysis of textual displays and denotative-cum-connotative descriptions of the pictorial valor, one is sure that this associative blending has the potency to yield resourceful meaning potential of the advertising communication nuances, as intended to convince the reading audience.

There are two textual constructions in figure 4, which are bold for readers to consume. These are: "Everyone needs a break" and "Happy Workers' Day". The formal is a declarative clause; the latter is a minor clause. For the fact that a minor clause in not analyzable, except when such fabrication has augmented elements, the authors will consider the minor clause not from its ranked structures but from a point of view of its contextual implication thereafter. As evaluated in figure 2, TXs la and 1b, NG and VG illuminate "Everyone needs a break" within the purview of 'Below the clause' as $N G$ recurs two times, VG functions just once.

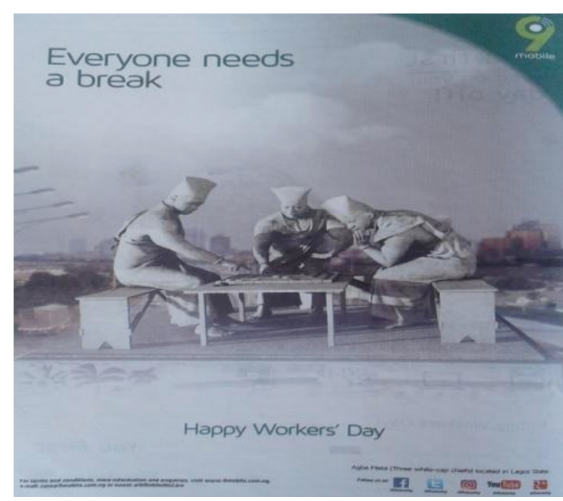

Figure 4. Nine mobile ad, 2018 Workers' Day

Source: The Punch Newspaper (2018, May 1).

The text points to all people in Nigeria to enjoy adequate rest on Workers' Day holiday. Nevertheless, if the text, "Happy Workers' Day", is averted, the audience might find it difficult to understand the kind of rest that the ad references. Workers' Day represents an industrial culture, not only in Nigeria, but in the entire globe, in which governments declare May $1^{\text {st }}$ as a free working day for workers (Foner, 1986; Heron $\varepsilon$ Penfold, 2005). Even those personnel on official duties receive due compensation from their employers. Significantly, there are images of the three 'wise' men illustrated in figure 4, sitting on benches and playing draft, as a form of exercise. On the one hand, "Everyone needs a break" and the pictorial representations of the three 'wise' men pass a message to recipients, as denoting relaxation. However, "Happy Workers' Day" demonstrates an anchorage function (Forceville, 1996), disclosing to readers the reason for playing draft at this point in time. 
Further observations exemplify the indeterminate nature of the three 'wise' men. This is owing to the fact that their dressing code's uniformity calls for questioning. It is not only alarming, shocking, and disgusting, but the decoration is also dreadful, appalling, and outrageous to appear in this way in a broad day light. Such attire is quite unusual in the entire Yorùbá culture. This apparel is trendy, which denotes a traditional ruler-ship group of the Lagos metropolis, popularly known as Isale Eko (the downtown portion of Lagos Island). The pictures project the chiefs, who support the Oba of Lagos to administer the traditional management of Isale Eko. There are no doubts that advertisers are opportunists, who are in search of novel materials to sensitize consumers (Ogilvy, 2013); this type of fashionable style is a scarce commodity.

The erection of the statues of the three 'wise' men at the entrance of Lagos, when someone is coming from Lagos-Ibadan expressway to Lagos, provides such a golden opportunity for the advertiser to persuade the target audience with traditional images. The 9 mobile ${ }^{\circledR}$ telecommunications firm, as the logo revealed at the upper right corner of the advertising plate in figure 4, perceives the pictures as good enough to fascinate the public. The telecommunications operator seems not to sell anything, nonetheless, the frame summarizes the textual-pictorial information with the revelation of 9 mobile, indicating the sponsor of the ad.

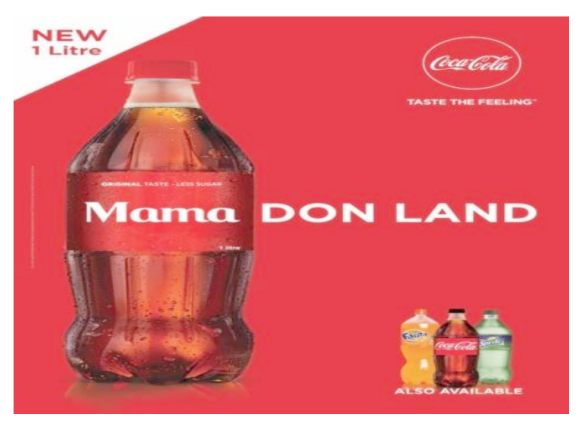

Figure 5. Coca-Cola ad, mama don land Source: field work.

Plate 2 in figure 5 contains both texts and images. The images do not project any matter of cultural endowment, however, the texts do. There are four images in the ad. That is, the big Mama bottle in a thematic posture, and the other big bottles of Fanta ${ }^{\circledR}$, Coca-Cola ${ }^{\circledR}$, and Sprite ${ }^{\circledR}$ at the downward part of the communication composition. These images are popular PET containers that suggest to recipients the products of The Coca-Cola Company. Besides, there are four clause formations, playing anchorage roles by providing meanings to the images of different colors (Braga, 2019). "New 1 Litre"; "Taste the feeling"; "Mama don land"; and "Also available" are the constructs that support the images. The NG, "New 1 Litre," introduces the Mama bottle appearance as a product that is recently manufactured as an unfamiliar good in the beve- 
rage market. It is an innovation, which is up-to-the-minute that the advertiser invites readers to come and "Taste the feeling", as indicated in TX 2b. The imperative clause has "Taste" as the VG and "the feeling" as the NG.

The publicist chooses "Taste" instead of drink as a sensational behavior of the tongue, luring consumers to respond to Coca-Cola's sweetening chemical compounds. The small savor might influence consumers to give preference to Coca-Cola for its acclaimed aesthetics. The intention of "Taste the feeling" seems a strategy to create a small amount of flavor experience of the quality of the drink for consumers. As a result of the flavored experience, the essence could stimulate individuals to be aware of the characteristics of the product. Adopting the thought of the advertiser might lead to high consumption of Coca-Cola.

"Mama don land" is Pidgin English and a code-switching entity (Sánchez-García, 2018). The analysts could interpret the statement as "Mama has arrived". By implication, in the perspective of the advertiser, "Mama" has, perhaps, travelled for some time. And at this moment, "Mama" has returned from the journey. Thus, all the other beverage products have to respect and honor "Mama". The employment of "Mama" instead of Coca-Cola fulfills the thought of Williamson's (2002) interchangeability. "Mama" represents a family culture. This illustration might connect us to the roles of women in home and larger society. Sánchez and Thomson (1997) and Coltrane (2000) herald women as mothers performing intermediary-cum-central tasks in a family or household. As Hersch and Stratton (2002), and Schneider (2011) expound the responsibility of women as manager, so also Henderson Daniel (2007) accentuates women from a leadership point of view in political and professional arenas. Therefore, Coca-Cola fastens on women's symbolic features to promote the "New 1 Litre" bottle or PET. The punctuated clause of $2 \mathrm{~d}$, "also available", acknowledges that the Fanta and Sprite varieties also have the indeterminate "Mama" trademark. One might match the plump appearance of "Mama" novel trade name with the seemingly tubby nature of the Nigerian woman.

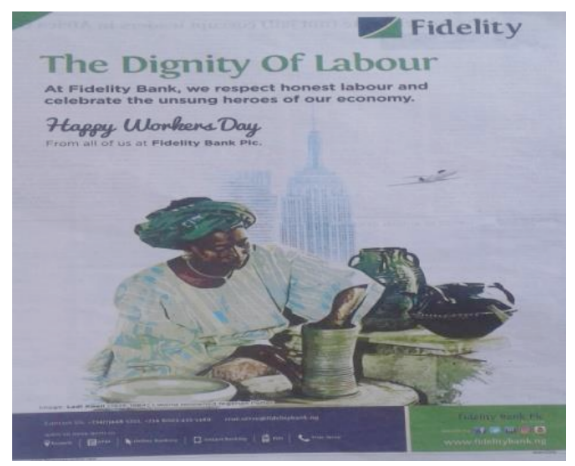

Figure 6. Fidelity Bank ad, 2018 Workers' Day.

Source: The Punch Newspaper (2018, May 1) 
TX 3a pinpoints the NG as the only systemic functional element of the fragmented clause, "The dignity of labour". Nevertheless, the complex, identified as TX $3 \mathrm{~b}$ and TX 3c, operates in four labels of 'Below the clause' group devices. Thus, the complex structure has Prep Ph, NG, VG, and Conj G. "At Fidelity ${ }^{\circledR}$, we respect honest labour", being the first simple clause, contains a marker: At Fidelity, introducing the clause to readers. The circumstance of location shows Fidelity as the place that the issue of "honest labour" admiration emanates from. In other words, Fidelity expresses the value for "honest labour" as the orbit of the firm's maxims. The choice of "honest labour" appears as a deliberate attempt. This is because the sponsor, Fidelity, emerged on top, is a financial institution.

Dealing in monetary activities demands faithfulness. Such requirement means that bank officials must be scrupulous in order to be careful and exact in conducting financial transactions, bearing in mind that a slight mistake can disrupt financial fidelity and can also erupt dangers of misappropriation. In other words, the bank personnel ought to demonstrate truth always, and should not be given to swindling. The deployment of "honest labour" is a financial institutions' cultural norm-cum-axiom, where all bankers are expected not to operate with deceitful methods. Such uprightness -at least in the banking industry- will reduce fraud (a crime of stealing and a tactic of obtaining illegal wealth through deception). As a way of discouraging false identity, the advertiser utilizes TX 3c, "and celebrate the unsung heroes of our economy", to influence readers, revealing a feature of the bank.

Significantly, the NG, "unsung heroes", is clear evidence that there are just workers in hidden places, who contribute immensely to the growth and development of the Nigerian economy. Such contributors, in Fidelity's recognition, are impeccable people in various terrains of the State. The image of the woman in the advertising frame, in the argument of the advertiser, represents a class of individual loyal to their employers and personal businesses. The choices of NGs of "The dignity of labour", "honest labour", and "unsung heroes" are communicative facilities of Fidelity Bank, exhibiting a form of allegiance to reliable trustworthy men and women. The image of the woman in action illustrates a process of using clay to produce pots in ancient times, and perhaps, in local villages in Nigeria.

Ordinarily, the materialization of the picture does not seem to have a relationship with the banking industry. However, the texts -which perform an anchorage functionreveale the meaning potential of the active woman (Dyer, 2005). On the one hand, the picture is determinate by signifying an iconic image of a woman molding a pot in an ancient culture. On the other hand, the texts illuminate the indeterminate depiction of the picture, elucidating the obligation, loyalty, and faithfulness of the dynamic woman to recipients (Cosio-Zavala \& Vilquin, 1997; Rodríguez-Modroño, Gálvez-Muñoz E 
Agenjo-Calderón, 2015). This connotes that Nigerian workers, in all walks of life, must regard dignity as utmost in their "honest labour". Furthermore, workers should consider themselves as "unsung heroes", without which the scale of the Nigerian economy can advance an inch. In respect to the qualities of workers highlighted above, Fidelity Bank management emotionally commemorates with Nigerian workers, as stressed in TX 3d, wishing individuals a "Happy Workers' Day".

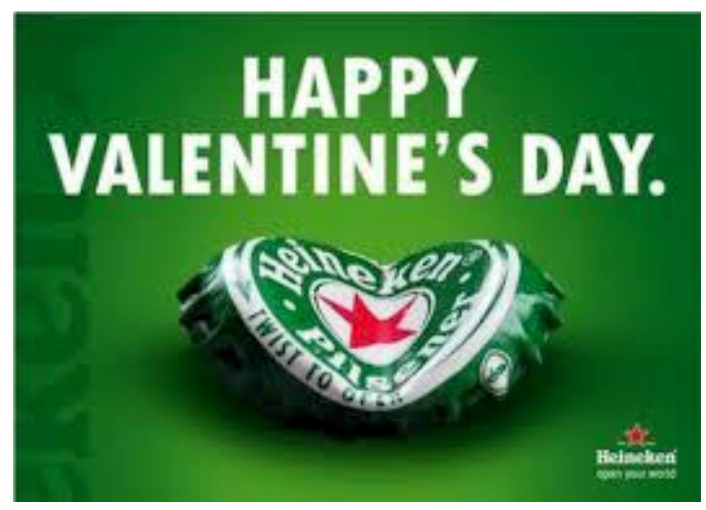

Figure 7. Heineken Ad, 2018 Valentine Day

Source: The Punch Newspaper (2018, February 14).

There are two displayed contents in Plate 4 shown in figure 7, text and image. Apart from the Heineken ${ }^{\circledast}$ label below the advertising frame, "Happy Valentine's Day" and "Open your world" are the major texts. Whilst "Happy Valentine's Day" remains a set construct, "Open your world" is an imperative statement, necessitating a command. The Valentine's Day is acculturated to religious histories. Historical accounts, such as Hoeh (n. d.) and Christensen (1997), state that Saint Valentine of Rome was imprisoned due to performing weddings for soldiers who were restricted to marry, and perhaps, for ministering to Christians (Pfatteicher, 2008). The authorities of the Roman Empire at that time persecuted Valentine for performing the marriage act. However, during his imprisonment, the priest healed the daughter of Asterius, his jailer. Before Valentine's execution, the ornamentation to this story reveals that Valentine wrote the woman a letter and decorated the cover with Your Valentine, as a farewell episode (Katella Senior Living Community, 2014). Although February 14 -being a month of romance, as declared by Pope in 498 AD- is the yearly celebration of Valentine's Day, hagiographical facts indicate that the celebration stated as far back as 270 AD. The Valentine's Day, Restored Church of God (2008) explains, is a day which is set aside as a romantic symbol, dedicated to celebrate love.

The association of Heineken with the religious-cum-cultural norm is to excite readers to consumption, enthusing consumers of alcohol in order to "Open" their "world". Contextually, "your world", NG, is indeterminate in the sense that the conno- 
tation represents Heineken. It is a logical premeditation of approaching recipients of the ad to "Open Heineken" and to drink its content. Moreover, the way in which the customized crown cork of Heineken is bent or fabricated, attracts one's attention. As a result, observations position the shape as a symbol of love (Vinken, 2000), making the image as connotative as the relaying text. The deployment of the ideographic shape of the human heart, Kemp (2011) asserts, expresses deep human affection for each other (a couple).

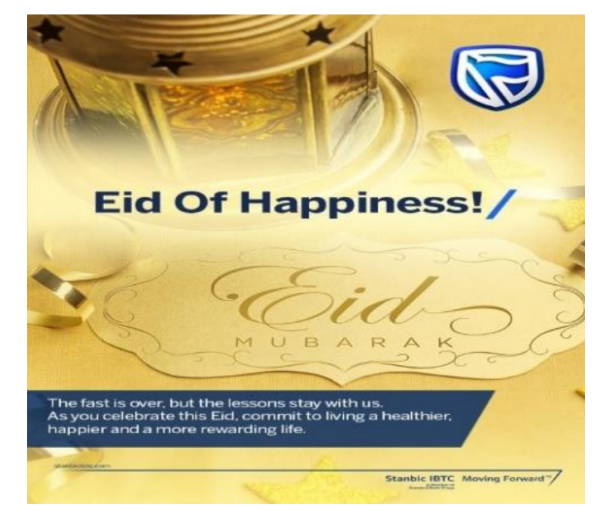

Figure 8. Stanbic IBTC Ad, 2018 Eid of Happiness

Source: The Punch Newspaper (2018, June 15).

The blue-white color logo at the upper right-side corner of Plate 5 in figure 8 signifies Stanbic IBTC ${ }^{\circledast}$ as the ad's sponsor. Tx $5 a$ and Tx $5 b$ are two structures of a purpose. "Eid of happiness" and "Eid Mubarak" suggest a kind of Muslim festival to the public. Although Stanbic IBTC is a bank, the propagation of the ad at this point in time is to demonstrate the management's love to the target audience. This is a kind of partnership that pinpoints 'I care about you' to Muslim brothers and sisters. The first clause of the texts, that is, "Eid of happiness!" is code mixed and punctuated (Oliveira $\&$ Gallardo, 2019) because "Eid of happiness!" is a combination of a NG and Prep Ph. To this end, the copywriter has deleted the mood of subject and finite from the clause. It is not out of place to suggest this is as the averted NG and VG of the clause (Thompson, 2014). "Eid of happiness!" with a mark of emphasis, motivates readers, endorsing individuals as possessors of emotional joy accommodated in fruity elegance.

The background illustrates the minor clause, "Eid Mubarak", as the greeting blueprint of the ad. "Eid Mubarak", in Griffiths' (2018) perspective, is a holy time of sacrifice for Muslims after the 30-day fasting period. The holiday, Griffiths adds, must be accomplished with remarkable and beautiful gifts to friends and families. Eid Mubarak has a relationship with Eid al Fitr for marking the end of Ramadan, and the beginning of the month of Shawwal. Furthermore, 'Eid' means merriment, while 'Mubarak' refers to a blessing of good things. Txs 5c, 5d, 5e, and $5 \mathrm{f} \mathrm{project} \mathrm{"Eid"} \mathrm{as} \mathrm{being} \mathrm{determinate.}$ 
"The fast is over; but the lessons stay with us" and "As you celebrate this Eid, commit to the living a healthier, happier, and more rewarding life" reveal the connection of Eid Mubarak with fasting. The advertiser acknowledges the festivity as a Muslim culture. In that regard, Stanbic IBTC seems to have turned to a preacher of righteousness, pinpointing to Muslims that those lessons of the fast must be adhered to. Goodwill messages must characterize their behavior as from this moment.

There is a need to celebrate, Stanbic IBTC attests, nevertheless, individuals must entrust their lives to activities that are more profitable to humanity. The fragmented "Stanbic IBTC moving forward" culminates the information, further exhibiting the sponsorship of the message. At the same time, the shibboleth provides meaning potential to the indeterminate logo of the bank, staying alone at the upper side of the right-hand corner. The Ka'aba-like golden image with a number of starry crests at the background elucidates a religious culture associated with Muslims during the Hajj exercise in Saudi Arabia. On the whole, Stanbic IBTC entwines itself with these exceptional Islamic cultural resources in order to elevate the morale of Muslims to patronize the services of Stanbic IBTC in Nigeria.

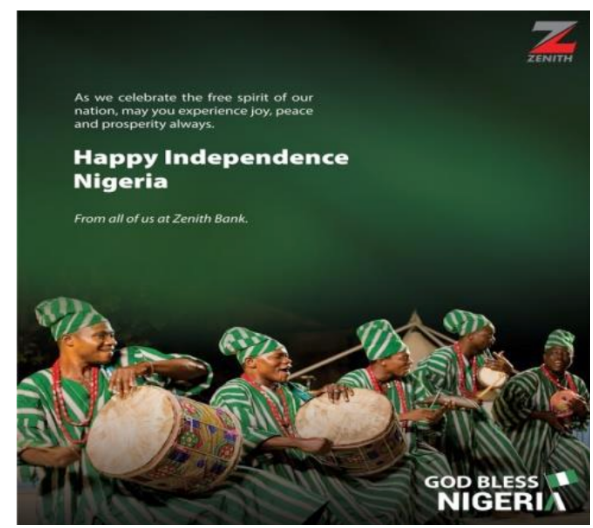

Figure 9. Zenith Bank Ad, 2018 Nigerian Independence Day

Source: The Punch Newspaper (2018, October 1).

In figure 9, the complex clause, "As we celebrate the spirit of our nation, may you experience joy and prosperity always", appears to have turned Zenith Bank ${ }^{\circledR}$ into a prayer warrior. One might comment that such approach might work well to coax recipients because Nigerians are religious people, who live daily on the results of their prayers, either as Muslims or Christians. Zenith's prayer-like characteristic reminds one that advertisers, all of them, are always in search of materials that can create opportunities to inveigle readers (Dalamu 2018b). Praying for Nigeria at Independence Day is a channel that acquaints Zenith with the Nigerian praying culture. "God bless Nigeria", as observed in Tx 6d, seems to connote the English slogan of God bless the 
Queen. "God bless Nigeria" schematizes the same religious culture of referencing the Almighty God. The minor clause connects Nigeria to God's concentration.

Considerably, "the spirit of our nation" in TX 6a seems indeterminate because the NG-cum-Prep Ph is a representation of connotative thoughts. These ideas, the writers might say, are usually epitomized in the Nigerian National Anthem, which are extensively discussed in the 1999 Nigerian Constitution. Thus, "the spirit of our nation" is an embodiment of elements that facilitates human virtues, leading to nation building, growth and development. The construction encourages the awakening of the giant in an individual to service, obedience to law and order. The structure inspires people to demonstrate love to fellow Nigerians in faith and operating in the landmarks of Nigerian past heroes. These qualities, in Zenith's essence, are as the treasures of the spirit of our nation. Freedom of expression, promotion of peace, and upholding unity are national values that support "the spirit of our nation". A submission to guideline documents and appreciation, being a Nigerian exemplifies much more of "the spirit of our nation".

The five-man picture, beating drums, singing, and dancing illustrate a culture of the Yorùbá nation (León, 2016; Toussaint, 2016). However, the men's green-white-green attire metaphorizes the Nigerian flag, typifying the national color. The drummers' fashion uniformity is a connotation that could provoke the public to cherish unity. These men in action are Nigerians, wearing Nigerian dresses, produced in Nigeria, and peacefully celebrating the Nigerian Independence.

The caps and dresses are products of adire (through the tie and die process), manufactured in Itoku, Abeokuta. The beads, as necklaces, are seemingly produced in Benin City; and the drum, known as bembe, is produced in Ijesha. Notably, the interplay of cultural phenomena displays two men who concentrate in beating bembe, one man beating agogo, one playing sekere (gourd musical instrument), and one man is responsible for beating gangan, the talking drum. In spite of the Yorùbá appearance of the five men, cultural devices of other nationalities are used to celebrate Independence Day. As a result of these traditional varieties, Zenith Bank calls for a team spirit among Nigerians in order to attain greatness in the comity of nations.

The declarative clause, "Your work will make Nigeria work", is the boldest text in Plate 7 shown in figure 10. By offering, the text labeled as 7a represents the theme of the advertising message (Kress $\&$ van Leeuwen, 1996). Two NGs and one VG are the configurations of the clause. The constituent facilities appear in these forms: "Your work" (NG) [...] will make [...] work" (VG), and "Nigeria" (NG). "Your work" as publicized in 7a is ambiguous (Lagerwerf, 2002). This is because the structure does not have a clear reference, positioning the group of words as being indeterminate. 


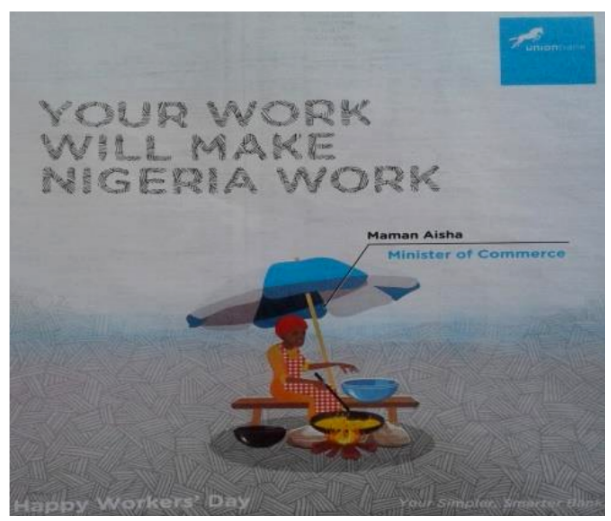

Figure 10. Union Bank ad, 2018 Workers' Day

Source: The Punch Newspaper (2018, May 1).

The researchers, in that position, might suggest two representational entities for a purpose of clarity: Nigerian workers and "Maman Aisha". The information openness of duality might have informed the analysts to ask this question: Does "Your work" refer to the Nigerian workers or to "Maman Aisha?" The concept of Nigerian workers seems to refer to salary earners in the public and private sectors. However, some sole proprietors and petty traders might be excluded from being among the 'Nigerian workers.' The point is that when the government declares the public holiday, sole traders and petty business owners do not participate in the event. Besides, increments in salaries do not positively and directly affect such business enterprises.

"Your work" entwines around industrial, office, and business cultures in their mega and medium scales, as governments hardly remember petty traders. Nonetheless, governments still collect taxes from such individuals. The VG "will make [...] work", articulates a future event. In a sense, everyone understands Nigeria's measure of values in terms of political and economic heights. Thus, the advancement of Nigeria from the known particular commercial viability depends largely on the individual's contributions. "Will make [...] work" operates as a source of encouragement to workers in their cultural, religious, biological and ethnic diversity. The goal of the NG is to sensitize people to work hard and labor vehemently for the growth and development of the nation. In addition, "will make [...] work" is visionary in nature. The construct sets a target to be achieved for workers in the nearest future.

There is a relationship between the image of the woman petty trader and the text, "Maman Aisha Minister of Commerce". The fundamental issue is that it is the text that relates the designation of the woman to recipients. This textual role, in the opinions of Najafian and Dabaghi (n .d.) and Danesi (2009), is a conceptually tagged anchorage. Besides the textual supportive revelation, the employment of "Maman Aisha" is salient. "Maman Aisha" is a woman political leader in Northern Nigeria. Precisely, "Maman 
Aisha" is a strong political echelon in Taraba State. Reports indicate that "Maman Aisha" is a local parlance emblem symbol with a full name, Hajia Aisha Jummai Al-hassan (Viashima, 2018).

Hajia Aisha Jummai Al-hassan is a lawyer who has held many offices in the country such as Minister of Women Affairs, Senator of the Federal Republic of Nigeria, Taraba State Attorney General and Commissioner of Justice, Secretary Federal Capital Judicial Council, and Chief Registrar of High Court, FCT, Abuja (Wikipedia, n. d.). Union Bank $^{\circledast}$ seizes the pedigree of the woman lawyer-politician as a means of reaching and exciting readers.

The production of the text and image has some implications. First, the authors obviously observe interchangeability (Müller, Alt \& Michelis, 2010) of Maman Aisha, the Minister of Women Affairs with being "Minister of Commerce". Second, the thin line that separates the text, "Maman Aisha" with the text, "Minister of Commerce" points to the woman-petty trader, roasting beans cakes under the umbrella. As the writers might remark that the connection of "Maman Aisha" to the petty trader is derogatory; it is also expedient to assert that the advertiser smartly sent a piece of information to all women-leaders in Nigeria. The association signals that the highfliers and career women must remember the plight of the womanhood and seriously fight that course. Courtesy, in Union Bank's standpoint, demands that women leaders must alleviate poverty among the women folks. Despite the certification that petty trader's contributions to the economy cannot be discarded with a wave of hand, the publicist, who is not novice, comprehends the sufferings of the Nigerian woman. "Happy workers' Day", as conveyed below the frame, serves as an avenue to communicate leaders about the anguish, distress, torment, and pains of being the downtrodden.

In conclusion, the ad introduces Union Bank as "Your simpler, smarter bank". Probably, the connotations of the text and image are not basically to motivate people to bank with this financial firm. Rather, Union Bank throws a challenge to every Nigerian - political leaders, business moguls, workers in various institutional domains, and petty business operators- that "Your work will make Nigeria work".

The advertiser deploys four clauses to campaign messages of Seaman's Schnapps ${ }^{\circledR}$. Apart from TX 8d, "Drink responsibly", all the other clauses are disjunctive grammatical elements. The chopped-up structures are Seaman's Schnapps in TX 8a, "Original No. 1 prayer drink" in Tx 8b, and "Blessed journey" in TX 8c. As Thompson (2004) recommends, one is at liberty to hint readers with the splintered textual facilities. On that ground, "[This is] Seaman's Schnapps", "[The Schnapps with the] original No. 1 prayer drink", "[Seaman's Schnapps wishes you al blessed journey" are seemingly the intended structures. Punctuated structures augment memorability (Leech, 1966), that is the motive for their consistency in advertising frameworks. 
The NG, "original No. 1 prayer drink", underscores two bonds of possibilities. On the one hand, the NG institutes a comparative analogy between Seaman's Schnapps and similar gin products in the market. Such claim, in the advertiser's point of view, entails Seaman's Schnapps as the best among its equals in the consumption hemispheres. This perspective gives rise to espouse the Schnapps as the "original No. 1." On the other hand, "prayer drink" explains Yorùbá cultural attitude of using gin to enhance the answering of prayers. The cultural belief exhibits a kind of respect to the soil, the deities, and to honor the dead (Adelowo, 1990; Catalani, 2006). Such traditional faith demands the elder in charge of the prayer and those individuals receiving the prayer to touch the portion of the libation on the ground to touch the individuals' foreheads three consecutive times. Seaman's Schnapps promoter launches deep into this traditional value to orchestrate the quality of the gin to the public as being parallel to the popular traditional taste.

"Blessed journey" in TX 8c ratifies the capitulation that Seaman's Schnapps is a "prayer drink". Hence, the ad begins to pray for travelers right away. It is important to reiterate that the analysts secured this ad from a main road leading to Murtala International Airport, Ikeja, Lagos. The thought, perhaps, might be that if anyone, in one way or another, has escaped the prayers of the elders through the pouring of libation, the message of the signboard has taken the responsibility of restoring missing opportunities. By implication, the ad provokes and overwhelms recipients to remember to buy Seaman's Schnapps for elders next time that such individuals are going home. The gin, to the publicist, appears as a better gift for elders rather than any other materials.

Two images are obvious in Plate 8 found in figure 11: the green bottle of Seaman's Schnapps and a hand decorated with beads, holding a glass, and pouring libation. The green bottle is simply iconic, as the container represents the renowned Seaman's Schnapps bottle and with a labeling indicator. The image of the hand with its operational activity is symbolic (Dyer, 2005). This is owing to the fact that the textual fragmentation reveals to the public the interpretation of the hand. As a result of the descriptions above, "prayer drink", "blessed journey", and the picture of a hand performing a traditional ritual communicate indeterminate information to viewers.

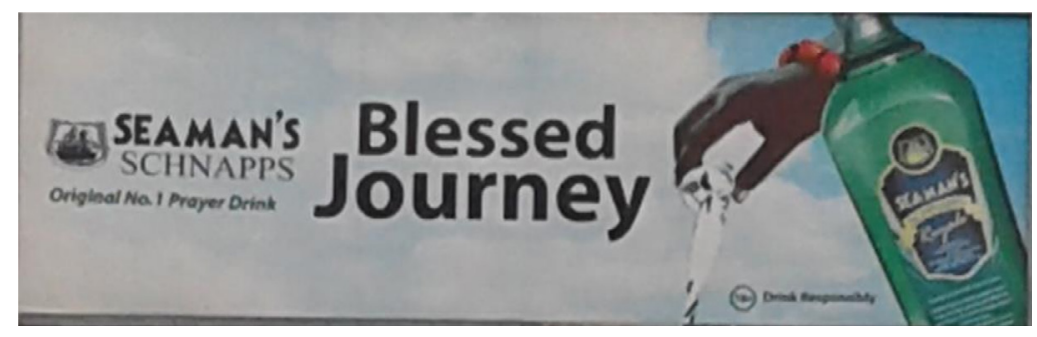

Figure 11. Seaman Schnapps Ad

Source: field work. 
United Bank of Africa $\left(\mathrm{UBA}^{\oplus}\right)$, as indicated in the top right-hand corner, is the sponsor of the ad. The two pronounced clauses in Plate 9 found in figure 12 are "May the sacrifice of Christ usher you into a new beginning"; and "Happy Easter", shown in TX 9a and TX 9b. The prayer-like phenomenon of Nigerian system of advertising in festivities, observed in TX 6b and TX 8c, continues in TX 9a. Therefore, "May the sacrifice of Christ usher you into new beginning" as a statement is a benediction for readers. This construct reveals a religious culture, linking viewers to Christianity. There are two NGs, two Prep Phs and one VG as constituents in TX 9a. Of importance are elements of NG "the sacrifice", and Prep Ph "of Christ". This expression, "the sacrifice of Christ", demonstrates the advertiser's awareness of Christian faith in Nigeria. One might comment that the copywriter uses the period as a bait to promote UBA to the public, most especially millions of Christian believers.
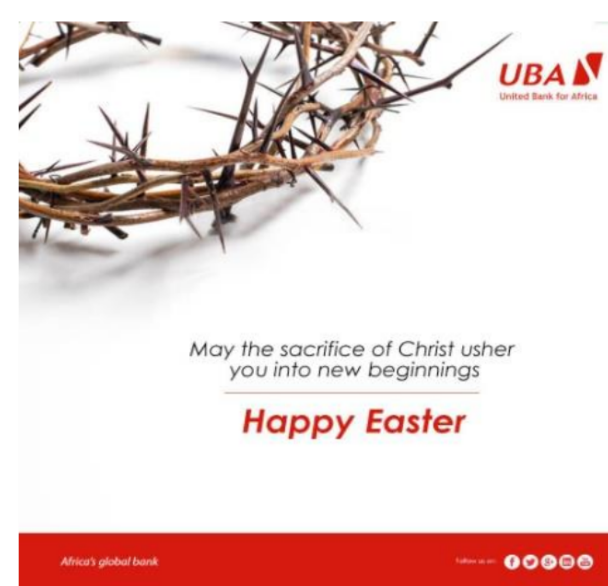

Figure 12. UBA Ad, 2018 Easter Celebration

Source: The Punch Newspaper (2018, April 1).

"The sacrifice of Christ" could appear indeterminate, however, the minor clause, "Happy Easter", manifests the nature of "the sacrifice" in question. To Christians, the offering of Christ through the cross is preeminence. That is why a celebration of Christ's resurrection marks the triumph of Christ and the followership over death and challenges of life (Christianity Today, 2018). In respect, the communicator utilizes the circumstance of location, "into a new beginning", to stimulate the morale of Christians. "Usher you into a new beginning" informs recipients that individuals have commenced a new but remarkable life as from now. The plate also displays some carved thorns, representing the crown of Christ at the Calvary (Thurston, 1913; Houlden, 2003; Nickell, 2007). Statements such as "the sacrifice of Christ" and "Happy Easter" reveal the indeterminate meaning of the 'holy thorn' to the general public. 
Plate 10 in Fifure 13 deploys the texts and images to persuade the target audience to consumption of Wema Bank ${ }^{\oplus}$ services. Exemplified in TXs 10a, 10b, 10c, and 10d, the four clauses are analogies of financial prudence of the bank. The complex clause, labeled as TX 10a and TX 10b, explicating a cultural forethought informs the argument that "Every kobo matters to us". "Kobo" (K) symbolizes a marker of the coin of naira (\#), the Nigerian currency as much as Penny typifies the coin of British pound sterling. In a nutshell, Wema Bank gives credence to "Every kobo" in their custody, understanding that it is the accumulation of a number of kobo that makes up millions. It seems also that some underprivileged customers might not like to forego a "kobo" for the bank. The bank projects a behavior of fidelity to consumers, expounding accountability of a sort.

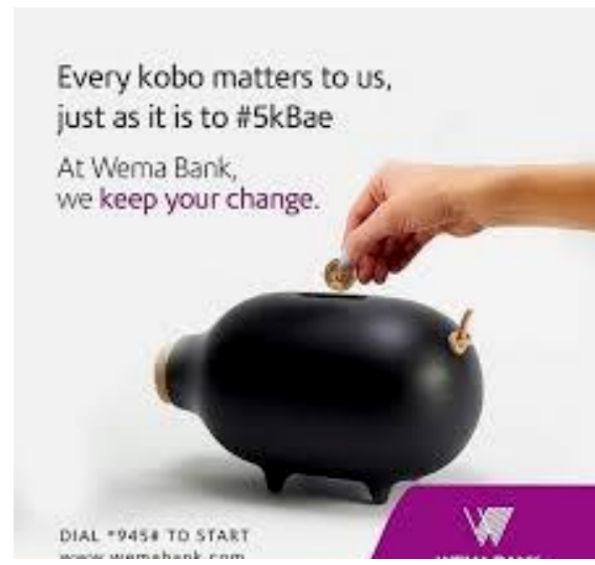

Figure 13. Wema Bank Ad, Bae (Kóló) Source: Ynaija (2017).

"Just as", in TX 10b, is a linguistic connector that establishes a characteristic comparison between Wema Bank and a personal home safe that appears as a pig-like toy or piggy-bank. The communication tags the saving container as "\#50kBae". The hashtag's sense shows that the pig-like container, known also as "kolo" in Yorùbá, can be purchased for 50k. Or that the "kolo" accepts to keep a small amount as low as 50k in its possession. The advertiser interchanges the financial protection-cum-humility of "Bae" as a referent for Wema Bank. "Bae" is a probable ambiguous notion (Arroyo, 1995), for the terminology can submit to imagery such as a British manufacturer of aircraft and electronic defense gadget, an expression of endearment as love for babes and sweet-hearted individuals. The writers might consider that Wema Bank's "Bae" represents a children's toy culture (Dalamu, 2020).

Apart from that, the "Bae" aptitude in keeping cash is somewhat limited. Nonetheless, the bank claims to operate in the lower capacity in order to take care of clients limited in financial power. Wema Bank, in the advertiser's point of view, is a 
friend to the poor. Apparently, that quality motivates the firm to argue that "At Wema Bank, we keep your change". TX 10d, "Dial *945\# to start" is fascinating, demonstrating the culmination of the message. The structures' meaning potential discloses that saving money does not compel an individual to visit the bank. Patronizing Wema Bank is operational through the telephone activity. The transaction is achievable by dialing *945\#, a business code of Wema Bank.

The texts and images portray a similar piece of information to receivers, positioning the two communicative devices as performing a relaying function (Gieszinger, 2001). The texts and images, in the writers' perspective, provide adequate meanings to the public in a reciprocal manner. The picture of someone's right hand illustrates an action of putting a coin in the piggy bank or kolo, exemplified as "\#50kBae". In addition, the ad exhibits a savings culture, financial prudence as a banking culture, and a baby culture as entwined around toys. These cultural features are simple denotations in the plate.

\section{Conclusion}

It is irrefutable that the culture of people is inseparable from individuals. That remark informs the attitude of advertising experts to utilize cultural norms as a means of convincing readers to consumption of goods and services. Thus, this study has exemplified cultural treasures as charismatic facilities in some advertising plates. Observations display assorted human cultures in textual constructs and pictorial imagery of the considered ads of the ten plates shown in figures 4 to 13.

From a structural perspective, elucidated in figure 2, NG dominates the texts, operating either as anchoring elements ("Mama don land") or relaying devices ("At Wema Bank, we keep your change") Besides, the facilities of VG as well as Prep Ph function next to the NG. As further demonstrated in figure 2, linguistic elements such as "needs" and "of happiness" in TXs la and 5a are content and adjunct structures, acknowledging processes and circumstances of the clauses. As there are punctuated clauses ("The dignity of labour"; "Stanbic IBTC moving forward"), so also are some clauses in their full-fledged simple forms ("The fast is over"; "Open your world"), producing meaning potential. Still within the 'Below the clause', Adv G "always"; "responsibly", and Conj G - "and"; "but" are other communicative apparatuses employed to sensitize recipients. The analysts observe minor clauses -"Happy Valentine's Day"; "God bless Nigeria"- that seemingly proliferate in the ads because of the festivity periods of their propagation. All these grammatical nuances contribute hugely to motivate readers.

The matter of determinate and indeterminate notions cuts across textual deployment and pictorial rendezvous. Regarding the texts, the employment of "Happy Workers Day", "Happy Independence", and "Happy Easter" projects a sort of festivity cultures, which are determinate to the concerned. Besides, most of the textual constructs -"Your 
work will make Nigeria work"; "Maman Aisha", "Minister of Commerce"- are indeterminate. This is because linguistic structures require some levels of logical calculations to elucidate the meaning potential in advertising frames. Concerning the images, the picture of the three 'wise' men in Plate 1 (figure 4), the bottle of Coca-Cola depicted as "Mama" in Plate 2 (figure 5), the fabrication of Heineken's crown cork in Plate 4 (figure 7), and the images in Plate 6 (figure 9) and Plate 7 (figure 10) are indeterminate articles. To a considerable extent, that is a probable raison d'être for the utilization of the text to play anchorage functions in order to reveal the appropriate meaning potential to the audience. Some images in Plate 4 (figure 7) and Plate 10 (figure 13), whose meanings are determinate, play relaying functions along with the texts.

As there are ambiguities in the messages of the advertising plates such as Plate 2 and Plate 10 (figures 5 and 13, respectively); the matter of cultural subjects dominates all the ads. This investigation pinpoints cultures in different dimensions in communications. Consequently, Plate 1, Plate 6, and Plate 8 (figures 4, 9 and 11) exhibit Yorùbá cultures in terms of 9mobile's Isale Eko traditional chiefs' dressing style, Zenith's traditional dressing code and appearance of men drumming-bembe-cum-dancing, and Seaman's Schnapps' traditional praying etiquette. Plate 2 (figure 5) displays family culture; whereas financial culture of honesty and banking culture of savings are socio-cultural dominions of Plate 3 and Plate 10 (figures 6 and 13). Significantly, the subjects of religion, which Nigerians are seriously dedicated to, are cultural hemispheres of Plate 4, Plate 5, and Plate 9 (figures 7, 8 and 12). Advertisers illustrate religious cultures in relation to Islamic and Christian faiths along with their prayer mannerisms.

In addition, there are multi-cultural applications of substances such as historical and love values in Plate 4 (figure 7), business and industrial norms in Plate 7 (figure 10), and a baby characteristic (in terms of toy) in Plate 10 (figure 13). Having realized that individuals cherish their cultures and hold the socio-cultural values at highest esteem, employing cultural resources to persuade the public is quite encouraging. The deployment of recipients' cultural materials gives the audience a sense of belonging and, at the same time, healthily influences people to flashback to their origins. Such fascinating communicative potential might create a kind of joy in the hearts of readers, most especially when the cultural resources are regionally sourced and integrated. Consequently, separating advertising from cultural norms could be detrimental to consumers and procedures. The affinity of advertising with cultural treasures promotes national values.

\section{References}

Adelowo, D. E. (1990). Rituals, symbolism and symbols in Yorùbá traditional religious thought. En African Journal of Theology 9, 162 173. http://www.obafemio.com/uploa ds/5/1/4/2/5142021/04-1_162.pdf 
Ahangar, A. A., Taki, G. E Rahimi, M. (2017). Identity: a cohesive device in some Persian live sport radio and TV talks. Acta Scientiarum. Language and Culture, 39(4), 397-406. https://doi. org/10.4025/actascilangcult.v39i4.34149

Alden, D. L., Hoyer, W. D. E Lee, C. (1993). Identifying global and culture specific dimensions of humor in advertising: a multinational analysis. Journal of Marketing, 57(2), 64-75. https://doi. org/10.2307/1252027

Allwood J. (1990). On the role of cultural content and cultural context in language Instruction. Gothenburg Papers in Theoretical Linguistics 60, 1-11. https://www.researchgate.net/profile/ Jens_Allwood/publication/2509809_On_The_Role_Of_Cultural_Content_And_Cultural Context_As_Language_Instruction/links/09e4151409d84bb3bb000000/On-The-Role-OfCultural-Content-And-Cultural-Context-As-Language-Instruction.pdf

Amaral, E. T. R. \& Oliveira, F. C. de. (2019). The influence of semantic factors in the use of general nouns for the subject indeterminacy. Acta Scientiarum. Language and Culture, 41(1), 1-11. https:// doi.org/10.4025/actascilangcult.v41i1.44977

Andrioli, F. E Ostermann, A. C. (2019). Understanding 'understanding' in teal classes: an interactional multimodal approach. Acta Scientiarum. Language and Culture, 41(2), 1-14. https:// doi.org/10.4025/actascilangcult.v41i2.46454

Arroyo, M. D. (1995). Lexical Ambiguity in Ads. Estudios Ingleses de la Universidad Complutense, (3), 187-200.

Assunção, C. E Araújo, C. (2019). A Lexicometric Analysis of the Poems from Guardador de Rebanhos. Acta Scientiarum. Language and Culture, 41(1), 1-11. https://doi.org/10.4025/ actascilangcult.v41i1.42079

Bakir, A., Palan, K. M. E Kolbe, R. H. (2013). A comparative content analysis of advertising practices to children. Journal of Current Issues E Research in Advertising, 34(2), 247-262.

Barthes, R. (1968). Elements of semiology. Hill Wang.

Bloor, T. E Bloor, M. (2004). The functional analysis of English. Hodder Arnold.

Bloor, T. E Bloor, M. (2013). The functional analysis of English 3th edition. Routledge.

Braga, J. (2019). Figurative convergence between body and image. Acta Scientiarum. Language and Culture, 41(2), 1-9. https://doi.org/10.4025/actascilangcult.v41i2.48668

Brierley, S. (1995). The advertising handbook. Routledge.

Burke, P. (2008). What is cultural history? Cambridge.

Carter, R. E Nash, W. (2013). Seeing through language, Blackwell.

Catalani, A. (2006). Yoruba religious material culture and the Yorùbá Diaspora: An investigation into the relationship between Yorùbá people in Britain and Yorùbá religious material displayed in British museums. [PhD Thesis, University of Leicester, UK]. Retrieved on $12^{\text {th }}$ December, 2018. https://pdfs. semanticscholar.org/67f7/d2040b6214d849a9447f0be5edfe33edea46.pdf

Chang, C. (2006). Cultural masculinity/femininity influences on advertising appeals. Journal of Advertising Research, 46(3), 315-323. https://doi.org/10.2501/S0021849906060296 
Christensen, M. L. (1997). Heroes and saints: more stories of people who made a difference. John Knox Press.

Christianity Today (2018). Easter. https://www.christianitytoday.com/ct/topics/e/easter/

Coltrane, S. (2000) Research on household labor: Modeling and measuring the social embeddedness of routine family work. Journal of Marriage and Family, 62(4), 1208-1233. https:// doi.org/10.1111/j.1741-3737.2000.01208.x

Cook, G. (2001). The Discourse of advertising. Routledge.

Cosio-Zavala, M. E. E Vilquin, É. (1997). Women status and family dynamics. Cicred, Unesco, http:// www.cicred.org/Eng/Publications/pdf/c-a32.pdf

Dalamu, T. O. (2017). Maternal ideology in an MTN ${ }^{\circledR}$ Advertisement: Analyzing sociosemiotic reality as a campaign for peace. Journal of Language and Education, 3(4), 16-26. https://doi.org/10.17323/2411-7390-2017-3-4-16-26/

Dalamu, T. O. (2018a). Euphemism: The commonplace of advertising culture. Acta Scientiarum. Language and Culture, 40(2), 1 15. https://doi.org/10.4025/actascilangcult.v40i2.41107

Dalamu, T. O. (2018b). English language development in Nigerian society: A derivative of advertising communications. Complutense Journal of English Studies, 26, 263-286. https://ssrn. com/abstract $=3304612$

Dalamu, T. O. (2019). Textual artifact of advertising: A thrust of Halliday's mood system resources. Revista Brasileira de Linguística Aplicada, 19(3), 407.454. https://doi.org/10.1590/1984 6398201912854

Dalamu, T. O. (2020). Discoursing children characteristics of Zenith bank ${ }^{\circledR}$, Nigeria, advertising: An expression of clause as representation. Journal of Language and Linguistic Studies, 16(1), 333365. http://www.jlls.org/index.php/jls/article/view/1271/558

Danesi, M. (2009). Dictionary of Media and communication. M. E.Sharpe, Inc.

Daramola, A. (2008). A child of necessity: An analysis of political discourse in Nigeria. Pragmatics: Quarterly publication of the International Pragmatics Association, 18(3), 355-360. https://journals. linguisticsociety.org/elanguage/pragmatics/article/view/596/513.html

De Mooij, M. (1998). Global marketing and advertising: Understanding cultural paradox. SAGE.

De Mooij, M. (2015). Cross-cultural research in international marketing: Clearing up some of the confusion. International Marketing Review, 32(6), 646-662. https://doi.org/10.1108/IMR-12 2014-0376

Dyer, G. (2005) Advertising as communication. Routledge.

Eggins, S. (2004). Introduction to systemic functional linguistics. Continuum.

Fam, K. S. (2008). Attributes of likeable television commercials in Asia. Journal of Advertising Research, 48(3), 413-427. https://doi.org/10.2501/S0021849908080422

Foner, P. S. (1986). May Day: A short history of the International Workers' Holiday, 1886-1986. International Press.

Fontaine, L. (2013). Analyzing English grammar: A systemic functional introduction. Cambridge University Press. 
Forceville, C. (1996). Pictorial metaphor in advertising. Routledge.

Gelbrich, K., Gäthke, D. E Westjohn, S. A. (2012). Effectiveness of absurdity in Advertising across cultures. Journal of Promotion Management, 18, 393-413. https://doi.org/10.1080/10496491.20 12.693058

Gevorgyan, G. E Manucharova, N. (2015). The effects of cultural appeal, product involvement, and ethnic identity on attitudes and recall in online advertising. Chinese Journal of Communication, 8(2), 196-220. https://doi.org/10.1080/17544750.2015.1014518

Gieszinger, S. (2001). The history of advertising language. Peter Lang GmbH.

Goddard, A. (2002). The language of advertising. Routledge.

Griffiths, J. (2018). Happy holiday. What does Eid Mubarak mean and is there a reply? The greeting said during Eid al-Adha. The Sun. https:/www.thesun.co.uk/news/3892203/eid-mubarak-meaninggreeting-reply-eid-al-adha-eid/

Hall, E. T. (1976). Beyond culture. Anchor Book, Doubleday.

Halliday, M. A. K. \& Matthiessen M. I. M. (2004). An introduction to functional grammar. Arnold.

Halliday, M. A. K. E Matthiessen M. I. M (2014). Halliday's introduction to functional grammar. Routledge.

Harris, M. (1976). History and significance of the emic/etic distinction. Annual Review of Anthropology, 5, 329-350. https://doi.org/10.2307/2949316

Henderson D. N. P. (2007). Women and leadership, developing transformational leaders: Theory to practice. Blackwell Publishing.

Heron, C. E Penfold, S. (2005). The Workers' Festival: A history of Labour Day in Canada. University of Toronto Press.

Hersch J. E Stratton L. S. (2002). Housework and wages. The Journal of Human Resources, 37, 217 229. https://doi.org/10.2307/3069609

Hoeh, H. L. (n. d.). Origins of Valentine's Day. http://www.british-israel.ca/Valentine.pdf.

Hoffmann, S., Schwarz, U., Dalicho, L. E Hutter, K. (2014). Humor in cross-cultural advertising: A content analysis and test of effectiveness in German and Spanish print advertisements. Procedia-Social \& Behavioral Sciences, 148, 94-101. https://doi.org/10.1016/j.sbspro.2014.07.022

Hofstede, G. (1980). Culture's consequences: International differences in work-related value. Sage.

Hofstede, G. (1997). Cultures and organizations: Software of the mind. McGraw Hill.

Hofstede, G. E Hofstede, G. J. (2005). Cultures and organizations: Software of the mind. McGraw-Hill.

Hornikx, J. E O'Keefe, D. J. (2009). Adapting consumer advertising appeals to cultural values: A meta-analytic review of effects on persuasiveness and ad liking. In C. S. Beck (Eds.), Communication yearbook (pp. 39-71). Lawrence Erlbaum.

Houlden, J. L. (2003). Jesus in history, thought, and culture. ABC-Clio Inc.

Hsu, S. Y. E Barker, G. (2013). Individualism and collectivism in Chinese and American television advertising. International Communication Gazette, 75(8), 695-714. https://doi. org/10.1177/1748048513482543 
Jeong, Kim., H. E Hwang, Y. (2016). What type of content are smartphone users addicted to?: SNS vs. Games. In Computers in Human Behaviors, 54, 10-17.

Katella Senior Living Community. (2014, febraury). The history of Valentine's Day. http://www. thegoodmangroup.com/_newsletters/Jan-pdf-gifs/katella_news.pdf

Kemp, M. (2011). The heart in Christ to coke: How image becomes icon. Oxford University Press.

Keyton, J. (2006). Communication research: Asking questions finding answers. McGraw-Hill Inc.

Khanh, N. T. T. \& Hau, L. N. (2007). Preferred appeals as a reflection of culture: mobile Phones advertising in Vietnam. Asia Pacific Business Review, 13(1), 21-39. https://doi. org/10.1080/13602380600652987

Kiziltan, N. E Ayar, Z. (2020). The impact of English classics on increasing learners' motivation and cultural awareness: A case in Turkish EFL classes. Journal of Language and Linguistic Studies, 16(1), 280-289. https://doi.org/10.17263/jlls.712818

Kress, G. E van Leeuwen, T. (1996). The grammar of visual design. Routledge.

Lagerwerf, L. (2002). Deliberate ambiguity in slogans. Document Design, 3(3), 245-260. https://ris. utwente.nl/ws/files/6761 164/Lagerwerf02deliberate.pdf

Lee, S., Khang, H. E Kim, Y. (2016). A cross-cultural perspective on televised political advertising during the presidential election between the US and South Korea: 1992-2012. Asian Journal of Communication, 26(2), 133-152. https://doi.org/10.1080/01292986.2015.1110605

Leech, G. (1966). English in advertising: A linguistic study of advertising in Great Britain. Longmans.

Leech, G. M. E Short, M. H. (1981). Style in fiction. Longman.

León, T. (2016). Polyrhtythmia in the music of Cuba. UC Riverside Diagonal: An Ibero-American Music Review, 1(2), 82-99. https://doi.org/10.5070/D81232941

Maffesoli, M. (2000). El mundo de las apariencias: Sabiduría del parecer. El instante eterno. El retorno de lo trágico en las sociedades posmodernas. Paidós.

Martin, J. R. E Rose, C. (2013). Working with discourse: Meaning beyond the clause. Bloomsbury Academy.

Moon, Y. S. E Chan, K. (2005). Advertising appeals and cultural values in television commercials: A comparison of Hong Kong and Korea. International Marketing Review, 22(1), 48-66. https://doi. org/10.1108/02651330510581172

Mueller, B. (1987). Reflections of culture: An analysis of Japanese and American advertising appeals. Journal of Advertising Research, 27(3), 51-59. https://files.eric.ed.gov/fulltext/ED271776.pdf

Müller J., Alt, F. E Michelis, D. (2010). Pervasive advertising. American Marketing Association. Retrieved on $10^{\text {th }}$ December 2018. https://pdfs.semanticscholar.org/4752/ dd4558526e31 lacb84fd01631ddb7a4c29e9.pdf

Myers, G. (1994). Words in ads. Arnold.

Najafian, M. E Dabaghi, A. (n. d.). Hidden language of advertising: A semiotic approach. Proceedings of the International Conference: Doing Research in Applied Linguistics, 20-26. https://pdfs. semanticscholar.org/f977/eefe6e79d79709388868296d21db39a7c81e.pdf 
Nelson, M. R. E Paek, H. J. (2008). Nudity of female and male models in primetime TV advertising across seven countries. International Journal of Advertising, 27(5), 715-744. https://doi.org/10.2501/ S0265048708080281

Niaz, A. (2001). Reflections of cultural values in advertising: A cross-cultural perspective. The New Jersey Journal of Communication, 9(2), 203-213. https://doi.org/10.1080/15456870109367409

Nickell, J. (2007). Relics of the Christ. University Press of Kentucky.

Nwabueze, E. (2009). Research method: An integrated approach. ABIC Books.

Ogilvy, D. (2013). Confession of an advertising man. Southbank Publishing.

Oliveira, W. C. E Gallardo, B. C. (2019). Keep calm and change the code: A code switching study on Facebook. Revista Brasileira de linguistica aplicada, 19(1), 205-227. https://doi.org/10.1590/19846398201913594

Patton, M. Q. (2015). Qualitative research and evaluation methods: Integrating theory and practice. Sage.

Pérez Flores, A. M. E Muñoz Sánchez, V. M. (2018). Deporte, cultura y sociedad: un estado actual de la cuestión. Revista de humanidades, 34, 11-38. https://dialnet.unirioja.es/descarga/ articulo/6462051.pdf

Pfatteicher, P. H. (2008). New book of festivals and commemorations: a proposed Common calendar of saints. Fortress Press.

Pollay, R. W. (1983). Measuring the cultural values manifest in advertising. Journal of current Issues and Research in Advertising, 6(1), 71-92. https://doi.org/10.1080/01633392.1983.10505333

Polyorat, K. E Alden, D. L. (2005). Self-construal and need for- cognition effects on brand attitudes and purchase intentions in response to comparative advertising in Thailand and the United States. Journal of Advertising, 34(1), 37-48. https://doi.org/10.1080/00913367.2005.10639179

Poynton, C. (1996). Amplification as a grammatical prosody: Attitudinal modification in the Nominal Group. In M. Berry, C. Butler, R. Fawcett \& G. Huang (eds.), Meaning and Form: Systemic Functional Interpretations. Meaning and Choice in Language: Studies for Michael Halliday LVII, (pp. $211-227)$. Abler Publication.

Prieler, M. E Centeno, D. (2013). Gender representation in Philippine television advertisements. Sex Roles, 69(5-6), 276-288. https://doi.org/10.1007/s1 1199-013-0301-4

Ravelli, L. (2000). Getting started with functional analysis of texts. In L. Unsworth (ed.), Researching Language in Schools and Communities (pp. 27-63). Continuum.

Resinger, S. (2010). Quantitative methods: Concepts, frameworks and issues. In L. Litosseliti (ed.), Research methods in linguistics (pp. 49-68). Continuum Group.

Restored Church of God (2008). The truth behind Saint Valentine's Day (3 ${ }^{\text {rd }}$ edition). https://rcg.org/ articles/ttbsvd.html

Riffo, K. F., Osuna, S. H. E Lagos, P. S. (2019). Lexical diversity and lexical density description of news written by journalism student. Revista brasileira de lingüística aplicada, 19(3), 499-528. https://doi.org/10.1590/1984-6398201914113 
Rodríguez-Modroño, P., Gálvez-Muñoz, L. E Agenjo-Calderón, A. (2015). The hidden role of women in family firms. Working Papers in History E Economic Institutions, 15(1), 1-23. http://www.upo.es/ serv/bib/wphaei/haei1501.pdf

Samovar, A., Porter, E. E McDaniel, R. (2009). Communication between cultures. Wadsworth.

Sánchez-García, D. (2018). Code switching practices in the discourse of two lecturers in Englishmedium instruction at university. Estudios de Lingüística Inglesa Aplicada, 18, 105-135. http:// dx.doi.org/10.12795/elia.2018.i18.05

Sánchez, L. E Thomson, E. (1997). Becoming mothers and fathers: Parenthood, gender, and the division of labor. Gender and Society, 11, 747-772. https://doi.org/10.1177/089124397011006003

Schneider, D. (2011). Market earnings and household work: New tests of gender performance theory. Journal of Marriage and Family, 73, 845-860. https://doi.org/10.1111/j.1741-3737.2011.00851.x

Sells, P. E González S. (2002). The Language of Consumer Advertising: Linguistic and Psychological Perspectives. In Studies in Linguistics and literature, 3(2), 95-126.

Sezgin, H. E Ozturk, M. (2019). Risk and management of textile waste: the impact of embedded multinational enterprises. In Nanoscience and biotechnology for environmental applications, environmental chemistry for a sustainable world, (2), 29-53.

Song, Y. A., Ahn, H. E Sung, Y. (2014). Cultural values in financial services advertising: a crosscultural study of magazine ads in the USA and Korea. Journal of Services Marketing 28(5), 349-360. https://doi.org/https://doi.org/10.1108/JSM-11-2012-0220

Sun, G., D'Alessandro, S., Johnson, L. W. E Winzar, H. (2014). Do we measure what we expect to measure? Some issues in the measurement of culture in consumer research. International Marketing Review 31(4), 338-362. https://doi.org/10.1 108/IMR-03-2012-0055

Theocharous, A. (2015). Food advertising as a mirror of intercultural differences: the case of the UK and Greece. British Food Journal, 117(4), 1256-1272. https://doi.org/10.1 108/BFJ-01-2014 0038

Thompson, G. (2004). Introducing functional grammar. Hodder Arnold.

Thompson, G. (2014). Introducing functional grammar. Routledge.

Thurston, H. (1913). Catholic Encyclopedia. Robert Appleton Company.

Toussaint, G. (2016). Classification and phylogenetic analysis of African ternary rhythm timelines. The International Society of the Arts, Mathematics, and Architecture (ISAMA), p. 25-36. https://pdfs. semanticscholar.org/d26f/26f97cf624d871651b29354c32614f661788.pdf

Triandis, H. C. (1972). The analysis of subjective culture. Wiley-interscience.

Vestergaard, T. E Schroder, K. (1985). The language of advertising. Basil Blackwell.

Viashima, S. (2018). 2019: Buhari, Atiku tear Taraba APC apart. The Sun Newspapers. https:// sunnewsonline.com/2019-buhari-atiku-tear-taraba-apc-apart/

Vinken, P. J. (2000). The shape of the heart: A contribution to the iconology of the heart. Elsevier Health Sciences.

Wikipedia (n. d.). Aisha Alhassan. https://en.wikipedia.org/wiki/Aisha_Alhassan 
Williamson, J. (2002). Decoding advertising: Ideology and meaning in advertising. Marion Boyars.

Xue, F. (2015). Message framing and collectivistic appeal in green advertising: A study of Chinese consumers. Journal of International Consumer Marketing, 27(2), 152-166. https://doi.org/10.1080 /08961530.2014.974118

Zhang, J. E Shavitt, S. (2003). Cultural values in advertisements to the Chinese X-generationpromoting modernity and individualism. Journal of Advertising, 32(1), 23-33. https://doi.org/10 $.1080 / 00913367.2003 .10639047$

Zhang, Y. (2014). Cultural messages in international advertisements. In H. Cheng (ed.), The handbook of international advertising research (pp. 271-298). Wiley-Blackwell. 